\title{
A morphological, phylogenetic and phylogeographic reappraisal of the land crabs Gecarcinus quadratus De Saussure, 1853, and G. lateralis Fréminville in Guérin, 1832 (Decapoda: Gecarcinidae). Are they different species?
}

\author{
IA ATZIMBA TOLEDANO-CARRASCO ${ }^{1,2}$, JOSÉ LUIS VILLALOBOS ${ }^{1 *}$ \& FERNANDO ÁLVAREZ \\ ${ }^{1}$ Colección Nacional de Crustáceos, Instituto de Biología, Universidad Nacional Autónoma de México, 04510 Ciudad de México, México

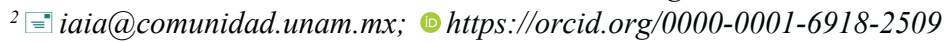 \\ ${ }^{3}$ ="falvarez@unam.mx; 내ttp://orcid.org/0000-0002-7347-5483 \\ *Corresponding author. =" hiriart@unam.mx; ๑ http://orcid.org/0000-0001-6810-2300
}

\begin{abstract}
Land crabs of the genus Gecarcinus are distributed along both versants of the American continent. At some point four species were recognized: G. lateralis, G. nobilii, G. quadratus, and G. ruricola. Taxonomically, several authors have tried to differentiate Gecarcinus lateralis from the Atlantic coast and G. quadratus from the Pacific coast. Because morphologic characters used showed high intra-population variability, identification were very difficult. Consequently, these two species have occasionally been considered synonyms. To establish the degree of genetic difference between them a molecular analysis was performed with both species, G. lateralis and G. quadratus, including Mexican Pacific and Atlantic specimens, using the mitochondrial COI and $16 \mathrm{~S}$ genes. The maximum clade credibility and maximum likelihood trees showed two clades with high support values, one corresponding to the Gulf of Mexico population and the other one to the Pacific coast population, with a genetic distance of $6.1 \%$. The within-clade average distance for the Atlantic populations (G. lateralis) was $1.1 \%$ and $0.2 \%$ for those of the Pacific coast (G. quadratus). This supports the status of $G$. quadratus as a valid species, not as a synonym of $G$. lateralis. The estimated time of divergence between both species ranged between 2.3 to 4.3 million years, coinciding with the proposed closure of the Isthmus of Panama. Morphologically, some populations show high variability in somatic characters, whereas sexual appendices of males of both species showed very little variation. Color in life, shape of sternite 3, and shape and degree of coverage of the abdomen of thoracic sternites, in both sexes, are traits that can be used to differentiate both species.
\end{abstract}

Key words: taxonomy, phylogeny, phylogeography, molecular dating, semi-terrestrial crabs

\section{Introduction}

The family Gecarcinidae H. Milne-Edwards 1837, is composed of semi-terrestrial crabs distributed in the tropical coastal plains of the Americas and in the southwestern Pacific region (Guinot et al. 2018). They inhabit mangrove forests, as well as inland areas adjacent to salt marshes, estuaries and coastal lagoons, where they play a significant role in the structuring and functioning of the coastal ecosystem, processing organic litter, recycling nutrients and aerating the soil (Jones et al. 1994; Sherman 2003; Griffiths et al. 2007; McGaw et al. 2019).

The genus Gecarcinus Leach 1814, is widely distributed in the American Continent. Currently, it contains four species. Two occur along the coast of the eastern Pacific: G. quadratus De Saussure, 1853, from the eastern coast of the Gulf of California, Mexico to Peru (Hendrickx 1995; Cuesta et al. 2007; Toledano-Carrasco 2019), and G. nobilii Perger \& Wall, 2014, in Ecuador and Colombia. The other two inhabit the western Atlantic coast: G. lateralis Fréminville in Guérin, 1832, occurs from Florida, USA to Venezuela (Toledano-Carrasco 2019), and G. ruricola (Linnaeus, 1758) is distributed from Florida, USA, to Nicaragua, including the Caribbean islands (Rathbun 1918; Chace \& Hobbs 1969; Perger \& Wall 2014). The taxonomic status of G. quadratus has remained questionable, as it has been regarded by some authors as a junior synonym of G. lateralis (Türkay 1973; Perger \& Wall 2014). Rathbun (1918), Powers (1977), von Prahl \& Manjarrés (1984), and Abele \& Kim (1986) tried to distinguish both species based on morphological characters that are highly variable within populations, such as the shape of the merus of the 
third maxilliped, the degree of coverage of maxillipeds with respect to the epistome of the buccal cavity, and the number of longitudinal rows of spines on the dactyli of pereiopods. This has led to misidentifications. For example, specimens of $G$. lateralis from northeast Mexico were identified as G. ruricola in some scientific collections. Due to this variable morphology, Türkay (1970) considered G. quadratus as a subspecies of G. lateralis; nevertheless, after reviewing the type specimens, he concluded that they were synonymous. Later, Perger \& Wall (2014) followed this idea and erected G. nobilii, including only three species as valid within the genus (G. lateralis, G. ruricola and G. nobilii) and suggesting the need of molecular analyses including different populations of Gecarcinus.

The aim of this study is to evaluate the taxonomic status of $G$. quadratus as a separate species, distinct from $G$. lateralis, employing molecular and morphological characters of specimens from the Pacific and Atlantic coasts of Mexico. Also, we re-evaluate the records of G. ruricola from Mexico with a view to recognize possible misidentifications.
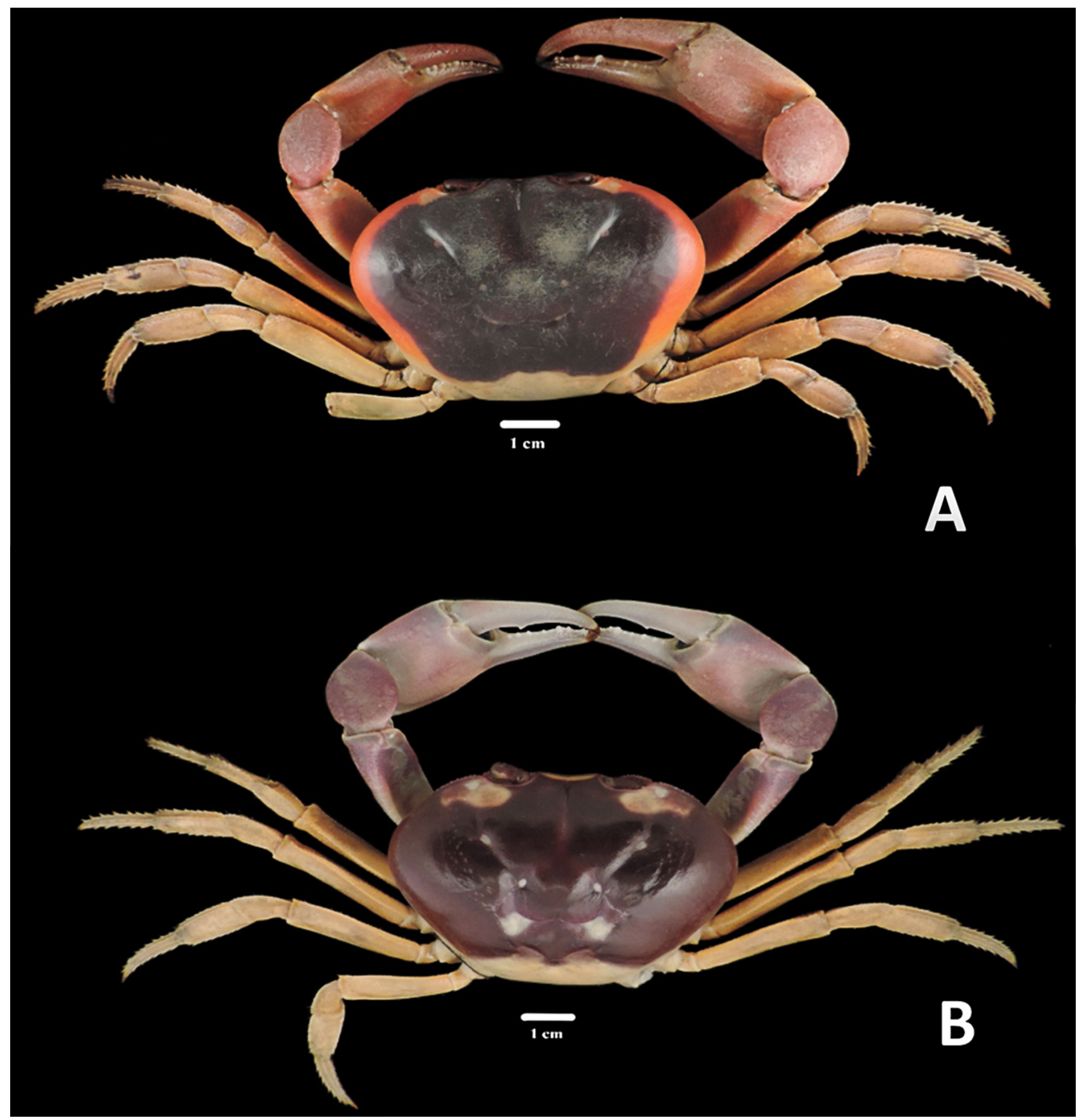

FIGURE 1. Dorsal view of: A) Gecarcinus lateralis from Río Prieto, Veracruz (CNCR 33942) and B) G. quadratus from Barra de Boca del Cielo, Chiapas (CNCR 34630). 

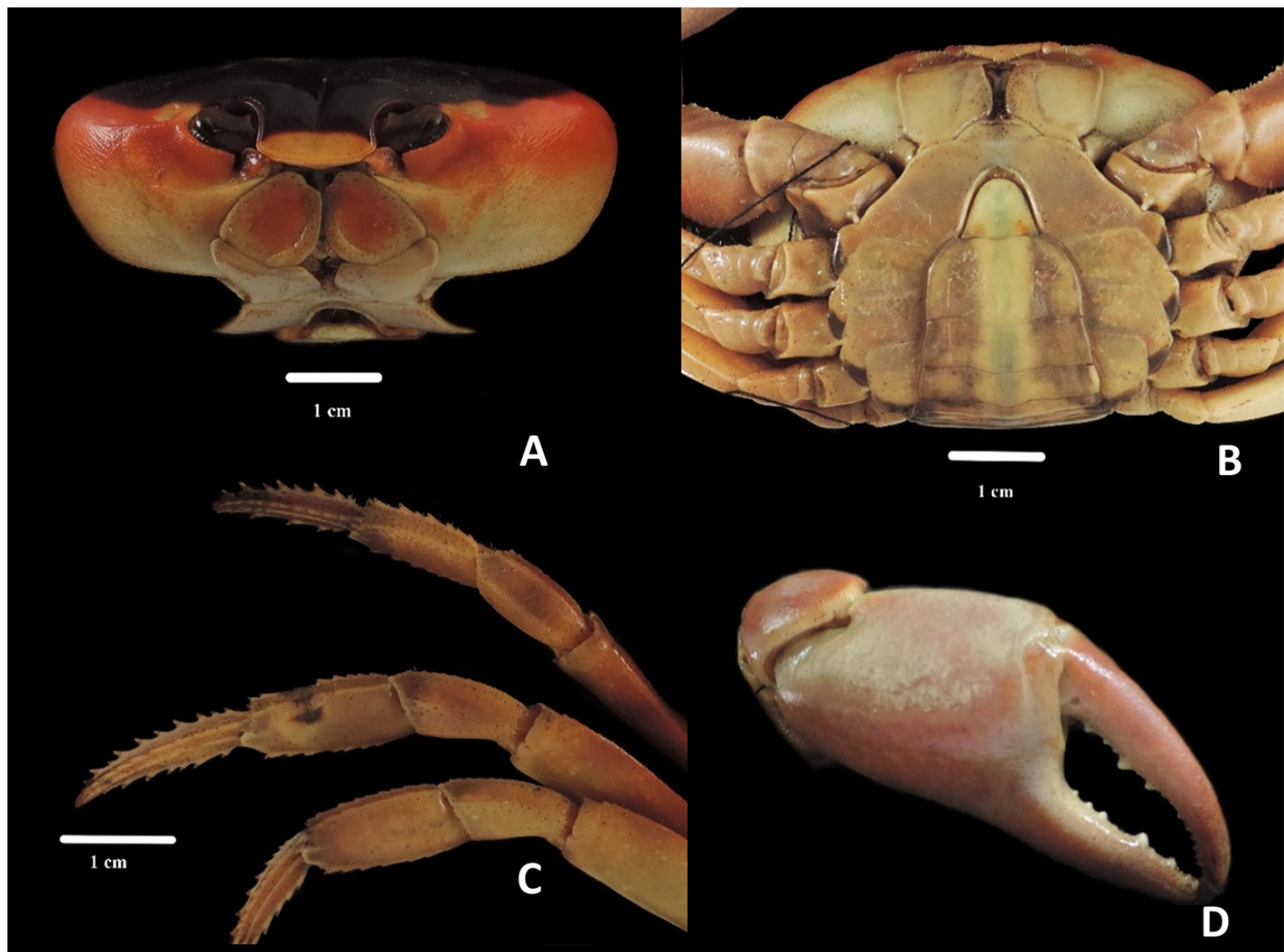

B

$1 \mathrm{~cm}$
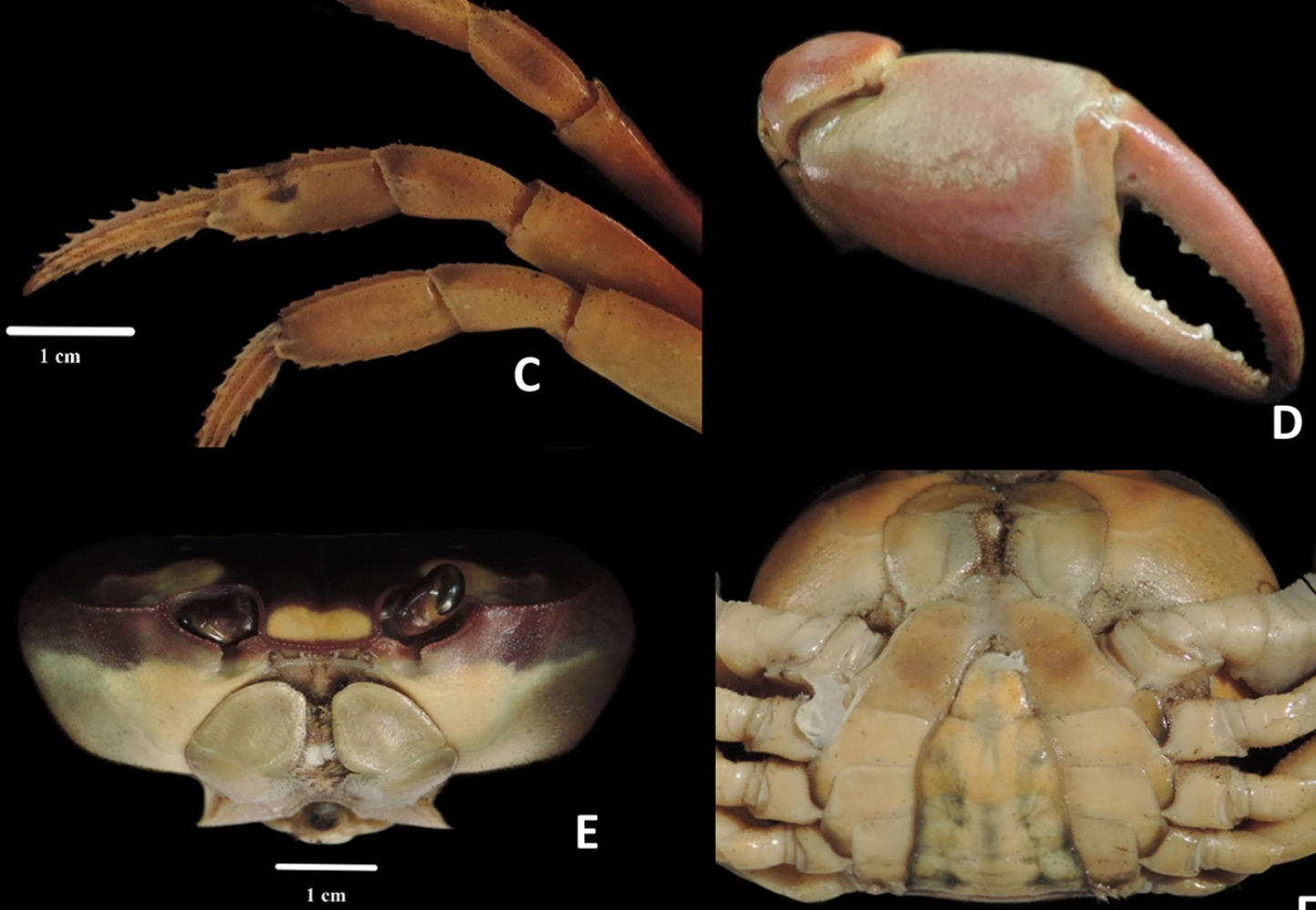

$\mathbf{E}$
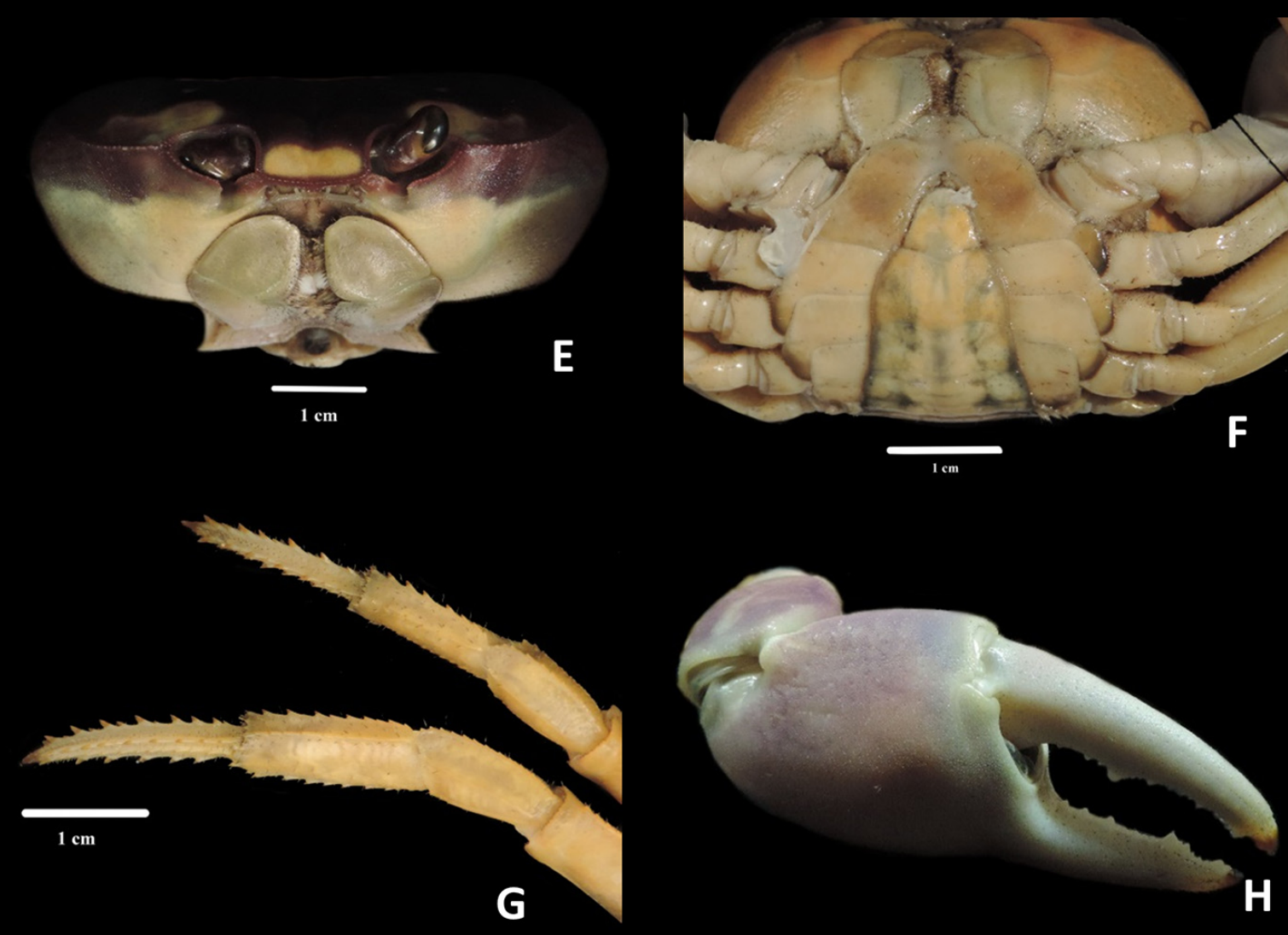

FIGURE 2. Gecarcinus lateralis from Río Prieto, Veracruz (CNCR 33942): A) frontal view, B) ventral vie, C) rows of spines in the dactyli of the pereiopods, D) major chela. Gecarcinus quadratus from Boca del Cielo, Chiapas (CNCR 34630): E) frontal view, F) ventral view, G) rows of spines in the dactyli of the pereiopods, H) major chela. 


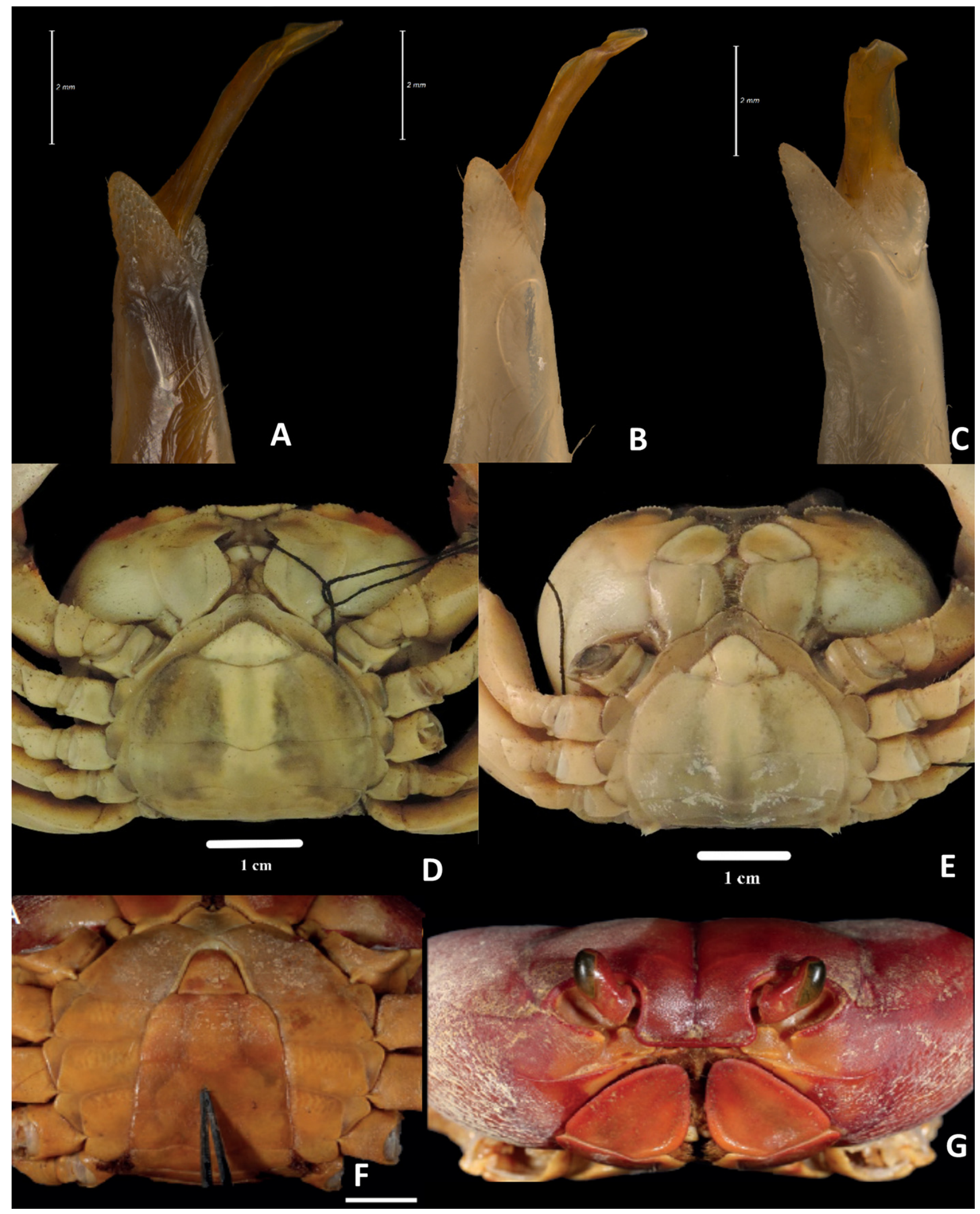

FIGURE 3. Left male first gonopod (G1): Cephalic view, A) G. lateralis from Río Prieto, Veracruz (CNCR 33942); B) G. quadratus from Boca del Cielo, Chiapas (CNCR 34630). Lateral view, C) G. quadratus from Boca del Cielo, Chiapas (CNCR 34630). Ventral surface, D) G. lateralis female from Barra de Sontecomapan, Veracruz (CNCR 33943); E) G. quadratus female from Playa Higuera Blanca, Nayarit (CNCR 34012); F) G. ruricola male from Cuba (MNHN-IU-2017-8392). Frontal view, G) G. ruricola from Cuba (MNHN-IU-2017-8392) (G. ruricola photos modified from Guinot et al., 2018). 


\section{Specimens available and morphological characters}

Fifty-six crabs belonging to Gecarcinus and one to Johngarthia Türkay, 1970, were analyzed, most of them (45) deposited in the Colección Nacional de Crustáceos (CNCR), Instituto de Biología, Universidad Nacional Autónoma de México. The other specimens included were: 10 crabs from the Colección Carcinológica del Laboratorio de Entomología y Artrópodos, Escuela de Biología, Universidad Autónoma de Nuevo León (CCLEA) and one crab from the Colección de Crustáceos de Yucatán (CCY), Unidad Multidisciplinaria de Docencia e Investigación, Facultad de Ciencias, Universidad Nacional Autónoma de México. The samples came from 23 different localities along the Mexican Pacific and Atlantic coasts. Additionally, four sequences (two COI, two 16S) of G. lateralis from Costa Rica and two (COI, 16S) from Panama, courtesy of F. Mantelatto (UNESP, Brazil), were included as well as a sequence of G. ruricola from Cuba, obtained from tissue of two pereiopods donated by C. Schubart (Universität Regensburg, Germany). The morphological description of the material examined was based on the terminology proposed by Perger \& Wall (2014) for the frontal and orbital structures. Guinot (1979) and Guinot et al. (2018) were followed regarding the ventral sternites and sutures that separate each somite. We followed Toledano-Carrasco (2019) for the gonopod description. The synonymy is restricted to the taxonomically important changes in each species. Measurements are in millimeters.

Organisms were morphologically compared and measured to find new characters that could correctly differentiate both species. A photographic catalog of the specimens was made taking three different views of the body, dorsal, ventral and frontal. The left first pleopod or male gonopod (G1), was photographed with a LEICA DFC490 camera adapted to a Leica Z16APOA dissection microscope. Photos of G. ruricola were reproduced from Guinot et al. (2018). The following abbreviations were used: carapace length (CL), measured along the midline, from the frontal to the posterior margin; carapace width $(\mathrm{CW})$, measured across the carapace at its widest point.

\section{DNA sequencing}

Genomic DNA was isolated from the gills or muscle tissue of specimens previously preserved in 70-80\% ethanol, following the protocol of the "Animal and Fungi DNA Preparation Kit, L pack" Kit. Polymerase chain reaction (PCR) was performed to amplify two mitochondrial genes, under the protocol of the MyTaq Kit. A fragment ( 635 base pairs (bp)) of the cytochrome c oxidase subunit I (COI) gene was amplified using the primers LCO1490 (5'-GGTCAACAAATCATAAAGATATTGG-3') and HCO2198 (5'-TAAACTTCAGGGTGACCAAAAAATCA$3^{\prime}$ ) (Folmer et al. 1994). The PCR conditions were denaturation for $45 \mathrm{~s}$ at $94^{\circ} \mathrm{C}$, annealing for $45 \mathrm{~s}$ at $48^{\circ} \mathrm{C}$ and extension for $1 \mathrm{~s}$ at $72^{\circ} \mathrm{C}(35$ cycles $)$, followed by a final extension for $8 \mathrm{~min}$ at $72^{\circ} \mathrm{C}$.

A fragment ( 539 base pairs (bp)) of the 16S rRNA gene was obtained using the primers 16Sa (5'-CGCCTGTTTACTAAAAACAT-3'), 16Sb (5'-CCGGTCTGAACTCAGATCACGT-3') (Daniels et al. 2006) and 16SAL2510 (5'-CGCCTGTTTATCAAAAACAT-3'), 16SB-H3080 (5'-CCGGTCTGAACTCAGATCACGT-3') (Kang et al. 2015). For the first set of primers the PCR program was: denaturation for $40 \mathrm{~s}$ at $95^{\circ} \mathrm{C}$, annealing for $40 \mathrm{~s}$ at $48-50^{\circ} \mathrm{C}$ and extension for $40 \mathrm{~s}$ at $72^{\circ} \mathrm{C}(35$ cycles $)$, and final extension for $10 \mathrm{~min}$ at $72^{\circ} \mathrm{C}$. For the second set of primers, the PCR program was: denaturation for $1 \mathrm{~min}$ at $94^{\circ} \mathrm{C}$, annealing for $1 \mathrm{~min}$ at $50^{\circ} \mathrm{C}$ and extension for 1 $\min$ at $72^{\circ} \mathrm{C}$ ( 35 cycles), followed by a final extension for $8 \mathrm{~min}$ at $72^{\circ} \mathrm{C}$. Sequences were obtained by automated sequencing on an Applied Biosystems $3500 \mathrm{xL}$ sequencer and were aligned manually, COI sequences with the aid of ClustalW implemented in MEGA 7.0.26 (Kumar et al. 2016) and 16S rRNA sequences with the algorithm L-INS-i, in MAFFT v7.397 (Katoh \& Standley 2013), after verification with the complementary strand. Additional 16S and COI sequences were downloaded from GenBank, for $16 \mathrm{~S}$ an organism from Punta Delgada, Veracruz (accession number AJ130804.2.), and for both genes, sequences of Johngarthia lagostoma (H. Milne-Edwards, 1837) were included (accession numbers: KT159739.1 and KM578842.1). Finally, Cardisoma guanhumi Latreille, 1828, was used as outgroup (accession numbers: MF490171.1 and MF490075.1).

\section{Phylogenetics and phylogeographic analysis}

Analyses were carried out separately for the COI and the 16S rRNA genes. The best fitting models for sequence evolution datasets were determined with jModelTest 2.1.10 (Darriba et al. 2012), selected by the Akaike information criterion with correction (AICc). The model for the first codon position of the COI gene was SYM $+1, F 81$ for the second and GTR for the third, while the model chosen for the 16S rRNA gene was GTR+G. A partitioned 
Bayesian inference analysis was performed with Mr. Bayes 3.2.2 on XSEDE (Ronquist et al. 2012) and the search was run with four chains for 100 million generations, with trees sampled every 10,000 generations. The sample of trees resulting was used to get the maximum clade credibility tree (MCC) in Tree Annotator v1.10.0 (Suchard et al. 2018); the first 10,000 trees were discarded since a stationary distribution was reached, these values were collected with Tracer v1.6. (Rambaut et al. 2014). The maximum-likelihood (ML) analysis was performed with the RAxML, implemented in Cyberinfrastructure for Phylogenetic Research (CIPRES) (Miller et al. 2010), using the default parameters and the GTR $+\mathrm{G}+\mathrm{I}$ model of evolution. The bootstrap was automatically determined during the run. The trees were observed and edited in Fig Tree v1.4.3 (Rambaut 2014).

Intraspecific and interspecific divergences were calculated with the COI gene sequences, using the Kimuratwo-parameter (K2P) substitution model (Kimura 1980), implemented in MEGA 7.0.26. The number of variable sites, the haplotype diversity $(\mathrm{Hd})$, and the nucleotide diversity $(\pi)$, for each gene, were calculated with the same program. The haplotype network of the COI gene was constructed using the Median-Joining algorithm (Bandelt et al. 1999) with Network 10.1.0.0 (https://www.fluxus-engineering.com/sharenet_rn.htm).

The approximate time of divergence was estimated by considering the COI substitution rates of $1.4 \%$ and $2.6 \%$ per million years, published for snapping shrimps belonging to the genus Alpheus from the Isthmus of Panama (Knowlton et al. 1993; Knowlton \& Weigt 1998).

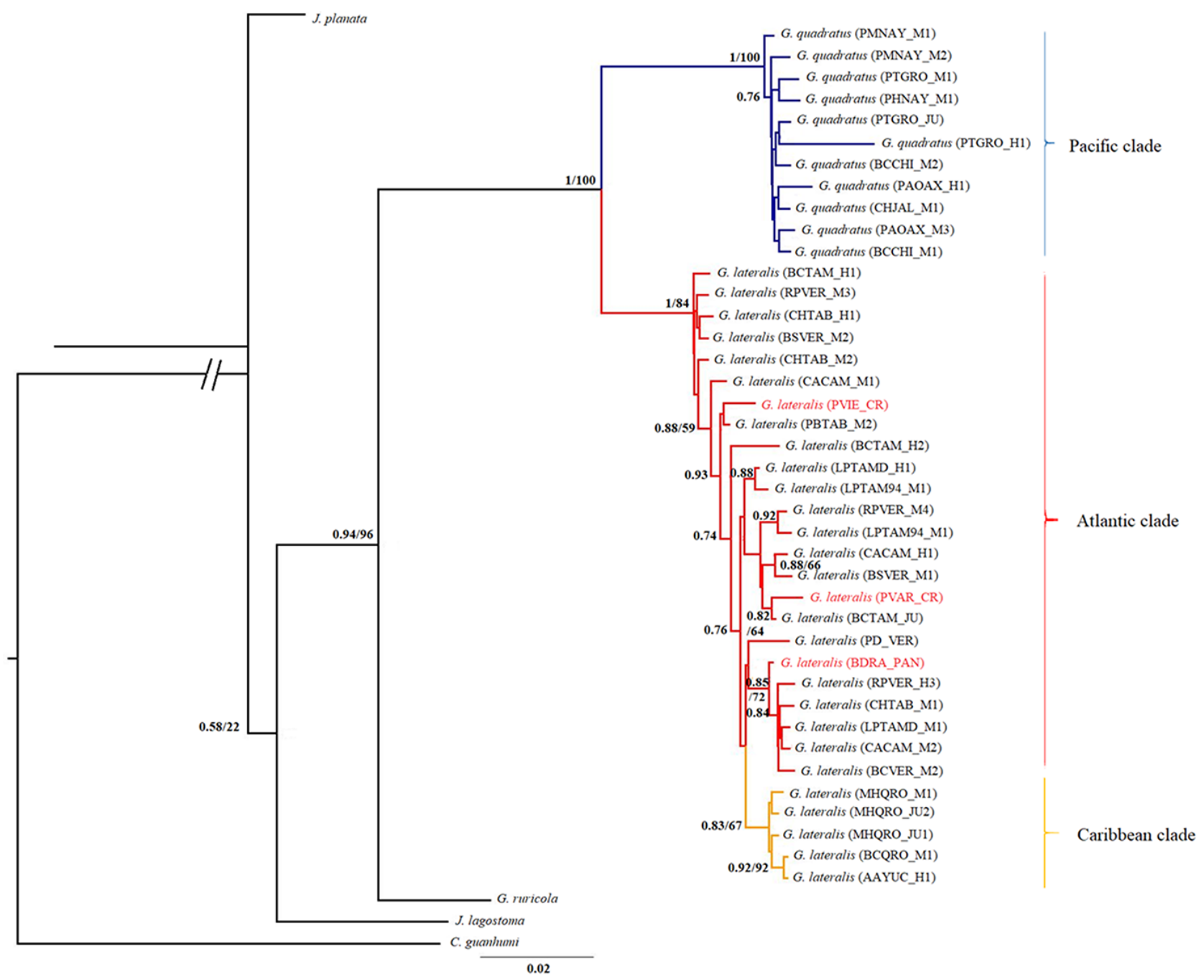

FIGURE 4. Maximum clade credibility tree based on Bayesian inference (BI) for Gecarcinus, Johngarthia and the outgroup, Cardisoma guanhumi, using the concatenated matrix of the 16S and COI genes. Probability values at the nodes refer to support values for BI and maximum likelihood (ML). In the assigned key for Mexican specimens, the last letter indicates the sex of the organism: male $(\mathrm{M})$, female $(\mathrm{H})$ or juvenile $(\mathrm{JU})$, followed by the individual number. The organisms highlighted in red in the Atlantic Clade correspond to specimens from Costa Rica and Panama. See the locality list in table 1. 


\section{Results}

\section{Phylogenetics and phylogeography}

A total of 40 COI sequences were included in the phylogenetic analysis: 11 of G. quadratus, 28 of G. lateralis, and one of G. ruricola (Table 1). A 635-bp segment of COI was amplified and aligned; 113 positions were variable and 55 parsimoniously informative, 20 different haplotypes were identified, 16 for G. lateralis and four for G. quadratus. For the $16 \mathrm{~S}$ gene, the 539-bp fragment had 101 polymorphic sites, 30 of which were informative, and nine haplotypes, five for G. lateralis and four for G. quadratus, were found (Table 2).

According to the $\mathrm{K} 2 \mathrm{P}$ genetic distance matrix, G. quadratus and G. lateralis differed by $6.1 \%$, while intraspecifically the distances were $1.1 \%$ for G. lateralis and $0.2 \%$ for G. quadratus (Table 3). The genetic distance between G. lateralis populations from the Gulf of Mexico and the Caribbean Sea was $0.6 \%$. Gecarcinus ruricola differed by $10.1 \%$ from G. quadratus and $9.6 \%$ from G. lateralis (Table 3).

Divergence time was estimated by using the average genetic distance between both the Pacific and the Atlantic clades, $6.1 \%$, and the COI mutation rates of $1.4 \%$ and $2.6 \%$ per million years, resulted in a time interval ranging from $2,346,153$ to $4,357,142$ years.

The phylogenetic tree based on the concatenated matrix of both genes (1,174 bp), was constructed using BI with the support values from BI and ML analyses. In all the analyses the separation of G. quadratus and G. lateralis as different clades was strongly supported; the specimens from Costa Rica (Puerto Vargas-PVAR_CR) and Panama (Bocas del Toro-BDRA_PAN) appeared immersed with those from the Gulf of Mexico. In addition, G. lateralis from the Caribbean grouped together next to the Gulf of Mexico specimens. The clade formed by G. quadratus and G. lateralis appears related to G. ruricola from Cuba. They, in turn are recovered as a sister clade of Johngarthia lagostoma, however, the branch support values were low. Johngarthia planata (Stimpson, 1860) is recovered as a separate clade, but only 16S sequences could be obtained for this species (Fig. 4).

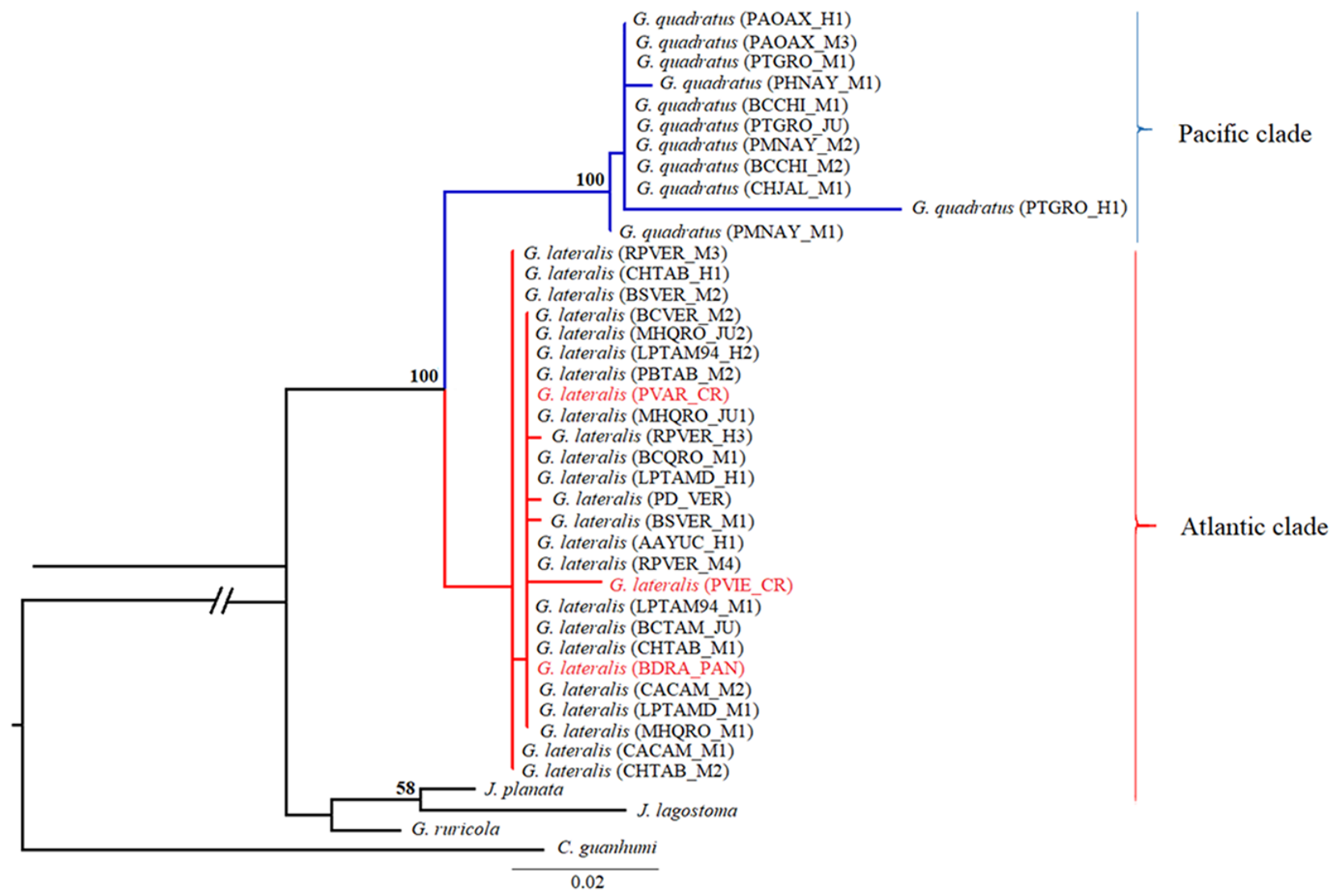

FIGURE 5. Maximum likelihood tree (ML) for Gecarcinus, Johngarthia and the outgroup, Cardisoma guanhumi, using the 16S gene. Probability values at the nodes represent support values for likelihood (ML). In the assigned key for Mexican specimens, the last letter indicates whether the organism is male (M), female (H) or juvenile (JU) followed by the individual number. The organisms highlighted in red in the Atlantic Clade correspond to specimens from Costa Rica and Panama. See the locality list in table 1. 


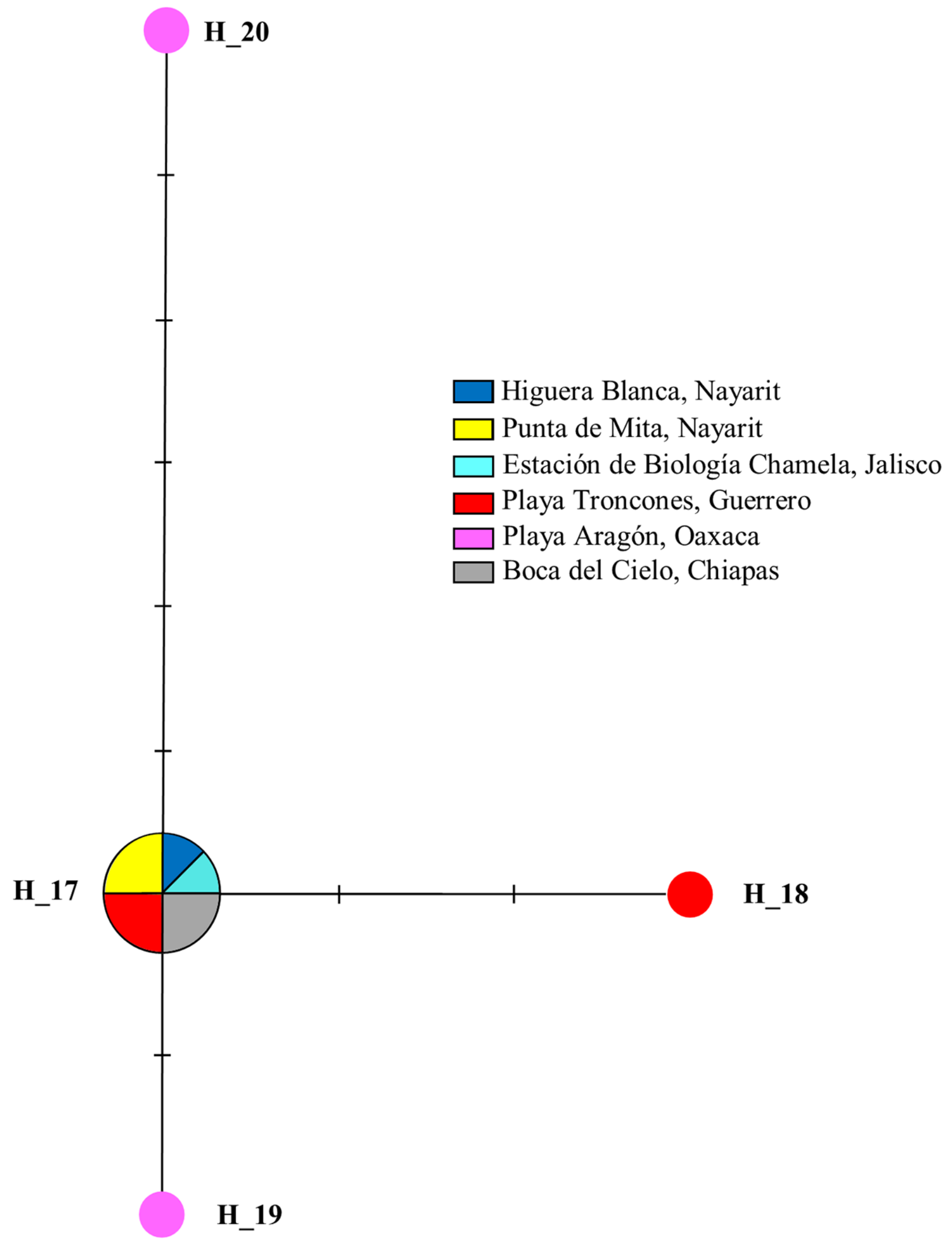

FIGURE 6. Median-joining network for Gecarcinus quadratus based on the alignment of the mitochondrial gene COI. Each middle line indicates one mutational step between haplotypes. Circles represent different haplotypes and their diameters the frequency of each. 
TABLE 1. Data of the organisms that were sequenced for both genes, including the catalogue number in the respective biological collections or the accession number in GenBank, the locality, the key assigned for each individual in phylogenetic and phylogeographic analyses. In the assigned key, the last letter indicates whether the organism is male (M), female $(\mathrm{H})$ or juvenile $(\mathrm{JU})$ followed by the individual number. The dashes represent sequences that could not be obtained, either because they could not be amplified or they were not available in GenBank.

\begin{tabular}{|c|c|c|c|c|c|}
\hline $\begin{array}{l}\text { Catalogue no./ } \\
\text { accession } \\
\text { number }\end{array}$ & Locality & $\begin{array}{l}\text { State of Mexico/ } \\
\text { Country }\end{array}$ & $\begin{array}{l}\text { Key assigned } \\
\text { for COI }\end{array}$ & $\begin{array}{l}\text { Haplotype } \\
\text { of COI }\end{array}$ & $\begin{array}{l}\text { Key assigned for } \\
16 \mathrm{~S}\end{array}$ \\
\hline CNCR 19003 & Playa Troncones & Guerrero & $\begin{array}{l}\text { PTGRO_H1 } \\
\text { PTGRO_M1 } \\
\text { PTGRO_JU }\end{array}$ & $\begin{array}{l}\mathrm{H} \_17 \\
\mathrm{H} \_18 \\
\mathrm{H} \_17\end{array}$ & $\begin{array}{l}\text { PTGRO_H1 } \\
\text { PTGRO_M1 } \\
\text { PTGRO_JU }\end{array}$ \\
\hline CNCR 34013 & Playa Aragón & Oaxaca & $\begin{array}{l}\text { PAOAX_H1 } \\
\text { PAOAX_M3 }\end{array}$ & $\begin{array}{l}\text { H_20 } \\
\text { H_19 }\end{array}$ & $\begin{array}{l}\text { PAOAX_H1 } \\
\text { PAOAX_M3 }\end{array}$ \\
\hline CNCR 33941 & Punta Mita & Nayarit & $\begin{array}{l}\text { PMNAY_M1 } \\
\text { PMNAY_M2 }\end{array}$ & $\begin{array}{l}\mathrm{H} \_17 \\
\mathrm{H} \_17\end{array}$ & $\begin{array}{l}\text { PMNAY_M1 } \\
\text { PMNAY_M2 }\end{array}$ \\
\hline CNCR 34012 & Playa Higuera Blanca & & PHNAY_M1 & H_17 & PHNAY_M1 \\
\hline CNCR 34630 & Barra de Boca del Cielo & Chiapas & $\begin{array}{l}\text { BCCHI_M1 } \\
\text { BCCHI_M2 }\end{array}$ & $\begin{array}{l}\text { H_17 } \\
\text { H_17 }\end{array}$ & $\begin{array}{l}\text { BCCHI_M1 } \\
\text { BCCHI_M2 }\end{array}$ \\
\hline CNCR 34846 & Estación Biología Chamela & Jalisco & CHJAL_M1 & H_17 & CHJAL_M1 \\
\hline C86-7182 & La Laguna & Tamaulipas & $\begin{array}{l}\text { BCTAM_H1 } \\
\text { BCTAM_H2 } \\
\text { BCTAM_JU }\end{array}$ & $\begin{array}{l}\mathrm{H}+3 \\
\mathrm{H} \_9 \\
\mathrm{H} \_7\end{array}$ & $\begin{array}{l}- \\
- \\
\text { BCTAM_JU }\end{array}$ \\
\hline C86-07094 & La Pesca & & $\begin{array}{l}\text { LPTAM94_H2 } \\
\text { LPTAM94_M1 }\end{array}$ & $\begin{array}{l}\text { H_5 } \\
\text { H_11 }\end{array}$ & $\begin{array}{l}\text { LPTAM94_H2 } \\
\text { LPTAM94_M1 }\end{array}$ \\
\hline FD & & & $\begin{array}{l}\text { LPTAMD_M1 } \\
\text { LPTAMD_H1 }\end{array}$ & $\begin{array}{l}\text { H_13 } \\
\text { H_6 }\end{array}$ & $\begin{array}{l}\text { LPTAMD_M1 } \\
\text { LPTAMD_H1 }\end{array}$ \\
\hline $\begin{array}{l}\text { C86-06601 } \\
\text { CNCR } 33942\end{array}$ & $\begin{array}{l}\text { Barra de Cazones } \\
\text { Río Prieto }\end{array}$ & Veracruz & $\begin{array}{l}\text { BCVER_M2 } \\
\text { RPVER_H3 } \\
\text { RPVER_M3 } \\
\text { RPVER_M4 }\end{array}$ & $\begin{array}{l}\mathrm{H} \_14 \\
\mathrm{H} \_13 \\
\mathrm{H} \_3 \\
\mathrm{H} \_12\end{array}$ & $\begin{array}{l}\text { BCVER_M2 } \\
\text { RPVER_H3 } \\
\text { RPVER_M3 } \\
\text { RPVER_M4 }\end{array}$ \\
\hline CNCR 33943 & Barra de Sontecomapan & & $\begin{array}{l}\text { BSVER_M1 } \\
\text { BSVER_M2 }\end{array}$ & $\begin{array}{l}\mathrm{H} \_10 \\
\mathrm{H} \_3\end{array}$ & $\begin{array}{l}\text { BSVER_M1 } \\
\text { BSVER_M2 }\end{array}$ \\
\hline $\begin{array}{l}\text { AJ130804.2 } \\
\text { (GenBank) }\end{array}$ & Punta Delgada & & - & & PDVER \\
\hline $\begin{array}{l}\mathrm{C} 86-06495 \\
\mathrm{C} 86-06500\end{array}$ & $\begin{array}{l}\text { Playa Bruja } \\
\text { Chiltepec }\end{array}$ & Tabasco & $\begin{array}{l}\text { PBTAB_M2 } \\
\text { CHTAB_H1 } \\
\text { CHTAB_M1 } \\
\text { CHTAB_M2 }\end{array}$ & $\begin{array}{l}\mathrm{H} \_3 \\
\mathrm{H} \_3 \\
\mathrm{H} \_15 \\
\mathrm{H} 33\end{array}$ & $\begin{array}{l}\text { PBTAB_M2 } \\
\text { CHTAB_H1 } \\
\text { CHTAB_M1 } \\
\text { CHTAB_M2 }\end{array}$ \\
\hline CNCR 34011 & Cayo Arcas & Campeche & $\begin{array}{l}\text { CACAM_H1 } \\
\text { CACAM_M1 } \\
\text { CACAM_M2 }\end{array}$ & $\begin{array}{l}\mathrm{H} \_8 \\
\mathrm{H} \_4 \\
\mathrm{H} \_13\end{array}$ & $\begin{array}{l}- \\
\text { CACAM_M1 } \\
\text { CACAM_M2 }\end{array}$ \\
\hline $\begin{array}{l}\text { YUC-CC-255-11- } \\
001024\end{array}$ & Arrecife Alacranes & Yucatan & AAYUC_H1 & H_1 & AAYUC_H1 \\
\hline CNCR 34010 & Mahahual & Quintana Roo & $\begin{array}{l}\text { MHQRO_M1 } \\
\text { MHQRO_JU1 } \\
\text { MHQRO_JU2 }\end{array}$ & $\begin{array}{l}\mathrm{H} \_2 \\
\mathrm{H} \_2 \\
\mathrm{H} \_2\end{array}$ & $\begin{array}{l}\text { MHQRO_M1 } \\
\text { MHQRO_JU1 } \\
\text { MHQRO_JU2 }\end{array}$ \\
\hline CNCR 30834 & $\begin{array}{l}\text { Isla Cayo Norte Menor, } \\
\text { Banco Chinchorro }\end{array}$ & & BCQRO_M1 & H_1 & BCQRO_M1 \\
\hline
\end{tabular}


TABLE 1. (Continued)

\begin{tabular}{|c|c|c|c|c|c|}
\hline $\begin{array}{l}\text { Catalogue no./ } \\
\text { accession } \\
\text { number }\end{array}$ & Locality & $\begin{array}{l}\text { State of Mexico/ } \\
\text { Country }\end{array}$ & $\begin{array}{l}\text { Key assigned } \\
\text { for COI }\end{array}$ & $\begin{array}{l}\text { Haplotype } \\
\text { of COI }\end{array}$ & $\begin{array}{l}\text { Key assigned for } \\
16 \mathrm{~S}\end{array}$ \\
\hline CCDB1520 & $\begin{array}{l}\text { Puerto Viejo, Limón } \\
\text { Puerto Vargas, Parque }\end{array}$ & $\begin{array}{l}\text { Costa Rica } \\
\text { (Atlantic) }\end{array}$ & PVIE_CR & H_3 & PVIE_CR \\
\hline CCDB1109 & Nacional Cahuita & Costa Rica & PVAR_CR & H_16 & PVAR_CR \\
\hline CCDB2553 & $\begin{array}{l}\text { Bocas del Drago, Bocas } \\
\text { del Toro }\end{array}$ & Panama & BDRA_PAN & H_13 & BDRA_PAN \\
\hline AM_Gruricola & Playa Larga & Cuba & G_ruricolaCU & & G_ruricolaCU \\
\hline CNCR 19002 & Playa Troncones & Guerrero & - & & J_planata \\
\hline $\begin{array}{l}\text { KT159739.1 } \\
\text { KM578842.1 } \\
\text { (GenBank) }\end{array}$ & - & - & J_lagostoma & & J_lagostoma \\
\hline
\end{tabular}

In general, clades obtained in the MCC tree for COI under the BI method showed high branch supports compared to those of ML (Fig. 4). Topologies of the 16S and COI fragments presented some discrepancies, particularly with regard to the position of G. ruricola relative to other Gecarcinus and Johngarthia. For the 16S tree under ML, clades from the Atlantic slope had low support values, while those from the Pacific formed a polytomy, excluding only one specimen from Punta Mita, Nayarit (Fig. 5).

Overall, Atlantic populations were genetically more diverse than those from the Pacific. For the COI gene, a total of 28 polymorphic sites and 16 haplotypes were obtained for G. lateralis with a $\mathrm{Hd}=0.5233$ and $\Pi=0.0099$. For the 16S gene, eight polymorphic sites and five haplotypes were obtained with a $\mathrm{Hd}=0.498$ and $\Pi=0.0016$. The Pacific populations of G. quadratus had eight polymorphic sites and four haplotypes for COI with a $\mathrm{Hd}=0.491$ and $\Pi=0.0023$. For the $16 \mathrm{~S}$ gene, 15 polymorphic sites were calculated. As a result, the degree of polymorphism was higher $(\Pi=0.0055)$ than for COI. However, the number of haplotypes and consequently the haplotype diversity had the same values (Tables 2, 3).

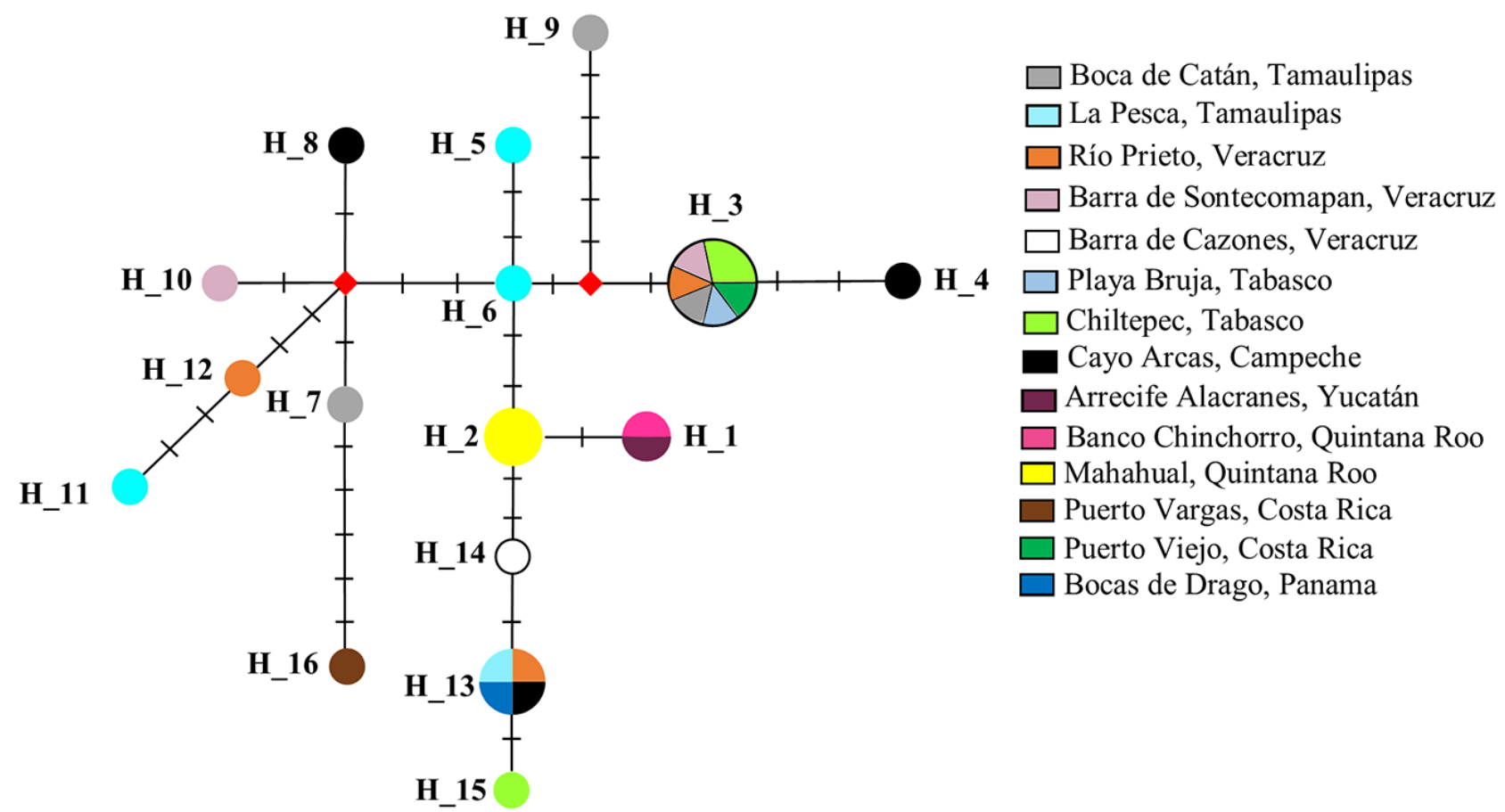

FIGURE 7. Median-joining network for Gecarcinus lateralis based on the alignment of the mitochondrial gene COI. Small red rhombuses correspond to missing or hypothetical haplotypes. Each middle line indicates one mutational step between haplotypes. Circles represent different haplotypes and their diameters their frequency of appearance. 
The haplotype network for the Pacific coast populations showed haplotype H_17 to be the most common one in eight individuals and distributed in five localities. Playa Troncones and Playa Aragón were the localities with two haplotypes, while the rest had one haplotype (Fig. 6; Table 1). In the Atlantic, the most frequent haplotype was H_3 with seven individuals, distributed in six localities, followed by the $\mathrm{H} \_13$ with four individuals in four localities. Playa Brujas, Tabasco (H_3) and Barra de Cazones (H_14) had one haplotype because only one individual was sequenced. In the Caribbean region, two haplotypes (H_1 and H_2) were found distributed in three localities, Mahahual and Banco Chinchorro in Quintana Roo and Arrecife Alacranes in Yucatán, of which H_2, had more organisms (Fig. 7; Table 1).

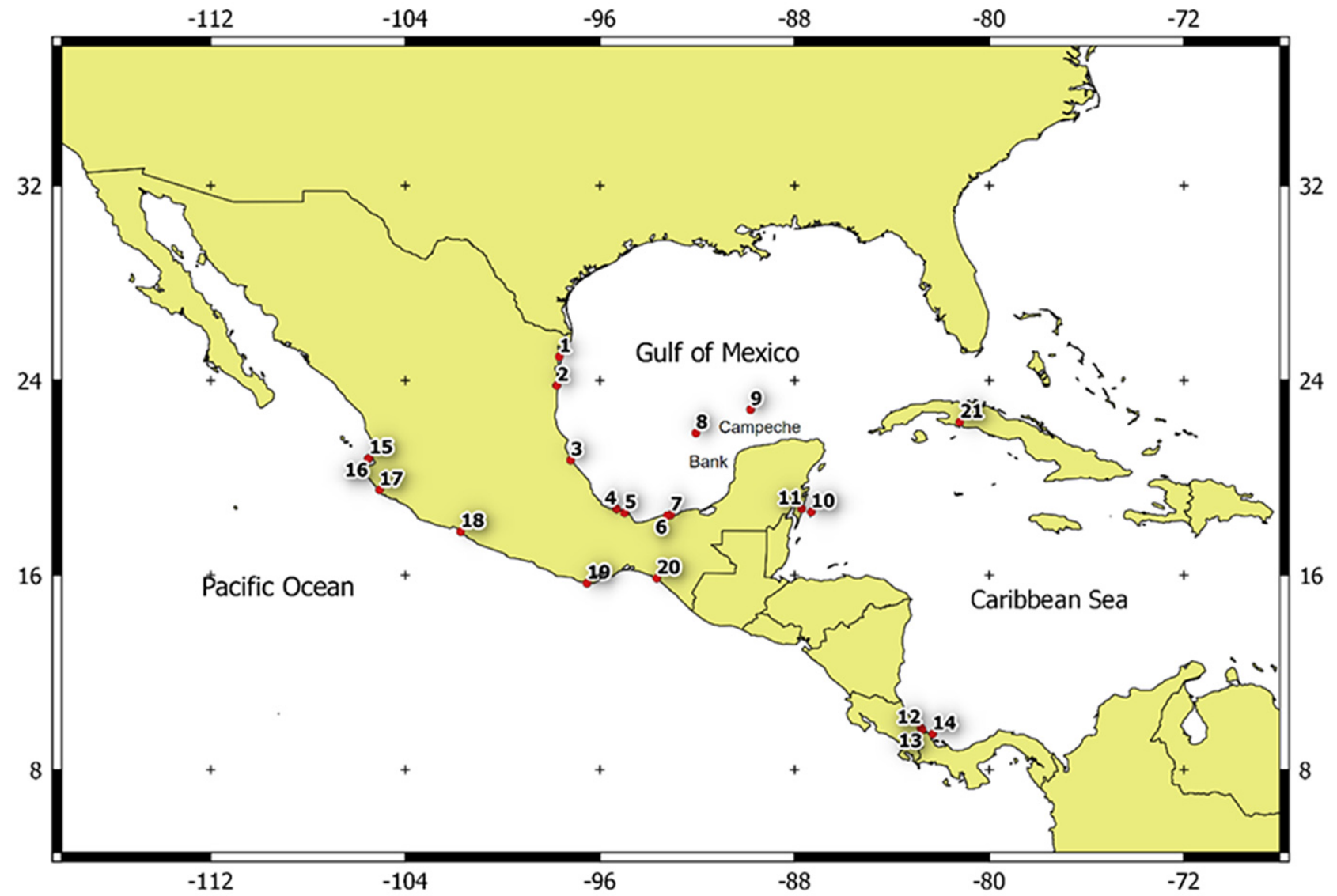

FIGURE 8. Localities of Gecarcinus lateralis and G. quadratus analized. 1) Boca de Catán, Tamaulipas. 2) La Pesca, Tamaulipas. 3) Barra de Cazones, Veracruz. 4) Río Prieto, Veracruz. 5) Barra de Sontecomapan, Veracruz. 6) Chiltepec, Tabasco. 7) Playa Bruja, Tabasco. 8) Cayo Arcas, Campeche. 9) Arrecife Alacranes, Yucatán. 10) Banco Chinchorro, Quintana Roo. 11) Mahahual, Quintana Roo. 12) Puerto Vargas, Costa Rica. 13) Puerto Viejo, Costa Rica, 14) Bocas del Drago, Panamá. 15) Playa Higuera Blanca, Nayarit. 16) Punta Mita, Nayarit. 17) Estación de Biología Chamela, Jalisco. 18) Playa Troncones, Guerrero. 19) Playa Aragón, Oaxaca. 20) Boca del Cielo, Chiapas. 21) Playa Larga, Cuba.

\section{Taxonomy}

Descriptions were based on 23 G. lateralis and 33 G. quadratus from Mexico. A diagnosis of Gecarcinus is provided followed by complete descriptions of both species.

\section{Genus Gecarcinus Leach 1814}

Diagnosis. Carapace transversely oval with branchial regions inflated. Pterygostomian regions glabrous. Anterior part of lateral border marked by marginal line. Fronto-orbital border $1 / 2$ or less than $1 / 2$ greatest breadth of carapace. Front strongly deflexed, frontal edge horizontal, from $1 / 5$ to $1 / 8$ the greatest breadth of carapace. Orbits deep, 
not much wider than high, outer angle obtuse, not prominent, inner angle as stout angular tooth touching inferior angle of front; a deep U-shaped sinus next to it. Eyes nearly filling orbits (Rathbun 1918). Proepistome hardly discernible, inserted under lower margin of narrow front (Guinot et al. 2018). Epistomal edge sometimes covered by third maxillipeds. Oral cavity subcircular or rhomboid, wider in the middle, margins with dense strip of bristles; third maxillipeds separated, central opening rhomboid, exposing mandibles; ischium and merus broad, subequal in length, merus suboval, hiding short and robust palp, the latter articulated in the middle of anterior margin of merus. Exognath hidden behind ischium, without flagellum, shorter than ischio-meral articulation. Chelipeds sturdy, almost smooth, in adults can be slightly or evidently different in size and robustness (smaller and weaker in females); internal surface of palm of major chela with or without tuberculated longitudinal ridge. Robust ambulatory appendages, second pair longest, last 3 joints armed with spines, dactyli with 4-6 longitudinal rows. First male pleopod (G1) semi-cylindrical, terminal apical element more than $1 / 3$ of G1 length, extending distally well beyond apex, as narrow, chitinous, semi-cylindrical structure, open with longitudinal furrow in lateral view, distal end widening in caudal and cephalic views. Main axis of G1 with suture mostly visible in mesial view, distal portion of cephalic surface, ending in finger-like projection, pointed and elongated or rounded and relatively short, directed apically or cephalically, ornamented with slender bristles extending distally (Fig. 3A, B) (Toledano-Carrasco 2019). In lateral view, distal portion of main axis excavated, ending in two projections, a corneous process and finger-like projection of cephalic surface; the former extending distally, rectangular, smoothly ribbed, ending obliquely with cephalic margin reaching beyond caudal one, the latter sharply triangular, about $1 / 2$ as long as the former (Fig. 3C). In caudal view, excavation of G1 main axis evident, corneous process inclined mesially. In cephalic view, apical plate directed distolaterally, fused to distal end of lateral surface, apically concave; marginal suture along cephalic surface of main axis (Fig. 3A, B) (Toledano-Carrasco 2019).

Sternal surface of carapace with bands of short setae between sternites 4-5. Sternite 1 as small triangular tooth, not separated by suture from sternite 2; sternite 2 semi-ovate or trapezoidal; suture $2 / 3$ straight, weakly marked, or V-shaped and well-developed; sternites 3-4 completely fused with straight or convex, obliquely directed lateral margins, thus not restricted at level of first pereopods (P1). Sternites 5-7 with similar shape, sutures well defined. Sternite 8 totally hidden when pleon is folded (Figs. 2B, F; 3D, E, F), posterior emargination reaching sternite 7 at level of narrow median bridge situated at level of suture $7 / 8$. Another weak median bridge present at level of suture 6/7 (G. ruricola) or traces of it (G. lateralis, G. quadratus). Male genital orifice completely sternal (Guinot, 1979). Sternites 3-4 with sterno-pleonal rim well-marked or rounded and slightly marked. Locking structure formed by button covered with setae in G. ruricola and G. quadratus (Köhnk et al. 2017; Guinot et al. 2018). Abdomen subtriangular in males, semi-circular in females, with 7 articulated somites in both sexes (Figs. 2B, F; 3D, E, F) (Toledano-Carrasco 2019). Margins of abdomen with dense tufts of hydrophilic setae, facing row of setae on adjacent portions of last sternites (Bliss 1963; Wolcott 1984), Müller's channel absent (De Oliveira 2014).

Remarks. Guinot et al. (2018) reexamined all gecarcinid morphological characters, and divided the family Gecarcinidae into two subclades. The first clade included: Cardisoma Latreille, 1828, Discoplax A. Milne-Edwards, 1867, and Tuerkayana Guinot et al., 2018; the second subclade, with a higher degree of terrestriality, included: Gecarcinus Leach, 1814, Gecarcoidea H. Milne-Edwards, 1837, and Johngarthia Türkay, 1970. Among the important characters shared by Gecarcinus and Johngarthia is the stridulatory apparatus, which is used to produce sounds when these crabs are disturbed in their retreats (Abele et al. 1973). The sound is produced when oblique rows of rugosities on the subhepatic region are rubbed against the tuberculated internal margin of the merus of the cheliped in G. quadratus, or against a longitudinal tuberculated ridge on the internal surface of the palm of the major cheliped in G. lateralis (Klaassen 1973; Abele et al. 1973).

The ability to absorb water from the substrate is well developed in Gecarcoidea natalis (Pocock, 1889) and Gecarcinus lateralis, in which setal tufts extend along the first three pleonal somites and on the coxa of P5 to establish a connection with the pericardial sacs (Bliss 1963, 1968; Greenaway 1988). In Gecarcinus ruricola and Gecarcoidea lalandii $\mathrm{H}$. Milne Edwards, 1837, the posterior margin of sternite 7 is lined with dense hydrophilic setae in contact with tufts of setae on the coxa of P5 and pleonal somites 1-3 (Guinot et al. 2018). 
Gecarcinus lateralis Fréminville in Guérin, 1832

(Figs. 1A; 2A-D; 3A, D)

Gecarcinus lateralis Fréminville in Guérin 1832: 7, pl. 5, figs. 1, 1a-b.

Ocypoda lateralis.-Fréminville 1835: 224.

Gecarcinus lateralis.-H. Milne-Edwards 1837: 27, pl. 18, figs. 1-6. De Saussure 1858: 440.

Geocarcinus lateralis.-Young 1900: 239.

Gecarcinus lateralis.-Rathbun 1918: 355. Chace \& Hobbs 1969: 198.

Gecarcinus (Gecarcinus) lateralis lateralis.-Türkay 1970: 337.

Gecarcinus (Gecarcinus) lateralis.-Türkay 1973: 974.

Gecarcinus lateralis.-Powers 1977: 139.

Gecarcinus (Gecarcinus) lateralis lateralis.—von Prahl \& Manjarrés 1984: 158.

Gecarcinus lateralis.-Abele \& Kim 1986: 661. Hernández-Aguilera 1996: 92. Schubart et al. 2006: 195. Ng et al. $2008: 215$. Felder et al. 2009: 1088. Low et al. 2013: 101. Perger \& Wall 2014: 97. Hermoso-Salazar \& Arvizu-Coyotzi $2015: 21$. Guinot et al. 2018: 568-570. Toledano-Carrasco 2019: 18-22. Ng et al. 2019: 99-100.

Material examined. MEXICO. Tamaulipas: 2 females, 1 juvenile, CCLEA C86-07182, Municipality San Fernando, La Laguna, Boca de Catán, Apr 04, 2014, coll. G. Rodríguez; 1 female, CCLEA, C86-07094, Municipality Soto La Marina, La Pesca, Oct 20, 2014, coll. G. Rodríguez; 1 male, 1 female, CCLEA C86-07094 jar D, same locality and collector data as previous, Sept 24, 2016.- Veracruz: 1 male, CCLEA C86-06601, Municipality Cazones, Barra de Cazones, Jan 24, 2015, coll. G. Rodríguez; 2 males, 1 female, CNCR 33942, Municipality Ángel R. Cabada, Río Prieto, coll. anonymous; 2 males, CNCR 33943, Municipality Catemaco, Barra de Sontecomapan, Apr 24, 2017, colls. I. Toledano, E. Moreno, J.L. Villalobos.- Tabasco: 1 male, CCLEA C86-06495, Municipality Paraíso, Playa Bruja, Oct 14, 2006, coll. G. Rodríguez; 1 male, 1 female, CCLEA, C86-06500, Municipality Paraíso, Chiltepec, Apr 06, 2007, coll. G. Rodríguez.- Campeche: 2 males, 1 female, CNCR 34011 Cayo Arcas, Apr 06, 2017, coll. anonymous; 1 female, CCY YUC-CC-255-11-001024, Municipality Progreso, Arrecife Alacranes, Aug 01, 2009, coll. C. Cinthya Delgado.- Quintana Roo: 1 male, 2 juveniles, CNCR 34010, Municipality Othón P. Blanco, Playa Mahahual, Mar 12, 2017, coll. Anonymous; 1 male, CNCR 30834, Isla Cayo Norte Menor, Banco Chinchorro, Mar 28, 2013, coll. anonymous.

Diagnosis. Male abdomen triangular; telson campanulate, narrower than sixth abdominal somite, lateral margins slightly marked, tip rounded. Sixth somite with convex lateral margins, forming lateral shoulder (Fig. 2B). Female abdomen subcircular, completely or almost completely covering thoracic sterna; telson triangular, as wide as posterior margin of sixth somite, lateral margins straight, smooth (Fig. 3D). Antero-lateral margins of sternite 3 slightly convex, those of sternite 4 straight, with slight concavity (Figs. 2B, 3D). Shallow endostomial ridges delimiting efferent branchial channel, poorly defining this region. Third maxilliped with merus generally concealing epistome. Adult male chelae different in size and robustness; inner surface of palm of major chela with longitudinal tuberculated ridge, used as stridulatory plectrum.

Description. Based on adult male with G1 well developed (54.3 $\mathrm{mm} \mathrm{CL}, 71.7 \mathrm{~mm} \mathrm{CW}$ ). Carapace transversely oval, wider anteriorly, strongly arched at level of branchial regions, anterolateral margin incipient, posterior portion of external orbital angle slightly marked, armed with minuscule granules. Regions well defined, delimited by shallow grooves. Branchial regions prominent. Fronto-orbital margin about $1 / 2$ of maximum carapace width (Fig. 1A). Front about $1 / 4$ length of carapace, deflexed, surface slightly concave, occasionally straight, inferior margin granulated, raised from surface, straight, generally concealing basal segments of antennules; frontal lobes poorly defined (Fig. 2A).

Orbits delimited by well defined, smooth superior border. Infra-orbital margin granulated, interrupted by deep notch, continued as triangular plate forming mesial lobe. Suborbital ridge well marked (stridulating crest of Guinot et al. 2018), extending from superior border of epistome to subhepatic suture. Surface of anterolateral wall of carapace reticulated (pars strident). Third maxillipeds not closing completely, leaving rhomboidal gap; merus covering epistome anteriorly, anterior border with medial notch, occasionally straight; ischium longer than merus, subequal in width. Palp short, hidden and articulated behind merus, directed laterally (Fig. 2A). Short exognath hidden behind ischium.

Strong heterochely in males, subequal chelipeds in females; fingers longer than palm, with corneous tips; longitudinal rows of granules throughout surface; cutting margins bearing 6-8 irregularly spaced blunt teeth; dactyl slightly curved inwards; fingers gapping (Fig. 2D). Internal surface of palm swollen, with distinct longitudinal ridge 
along midsection, used as stridulatory plectrum, internal depression next to articulation with carpus. Carpus subtriangular, dorso-mesial margin smooth in large organisms, spinulous in small ones. Merus elongated, subtriangular, internal border granulated.

Pereiopods (2-4) long, slender, with short setae; merus elongated, surface striated; carpus subtriangular, shorter than propodus, or almost of same length in fifth pair, dorsal margin toothed; propodus shorter than dactyl, dorsal and ventral margins formed by short, slender spines; dactyli armed with 4-6 rows of spines, those on lateral carina poorly developed to absent (Fig. 2C).

Male and female abdomen as in species diagnosis.

Male G1, as in genus diagnosis (Fig. 3A).

Female (39 mm CL, 33-50 mm CW), with gonopore on sixth plate of thoracic sternum, protruding. Ring around operculum oval, with sharp edges; operculum a large, oval, protruding lobe.

Coloration. Dorsal surface of carapace dark, lateral margins orange, posteriorly light cream. Chelipeds and lower portion of front orange (Fig. 1A)

Measurements. Males: 28.6-49.1 mm CL; 33.9-64.5 mm CW. Females 27.3-39 mm CL, 33-50 mm CW.

Remarks. The authorship of the species was attributed to Fréminville (1835) for many years who originally named organisms from the French West Indies: Marie-Galante, La Désirade, Guadeloupe and Martinique, as Ocypode lateralis. However, Low et al. (2013) reported that Guérin in 1832 had already used the name "Gecarcinus lateralis Freminv." in his Iconographie du Règne animal by G. Cuvier and, hence, he must be recognized as the author of the species.

\section{Gecarcinus quadratus De Saussure 1853}

(Figs. 1B; 2E-H; 3B, C, E)

Gecarcinus quadratus De Saussure 1853: 360. Rathbun 1918: 358. Garth 1948:58.

Gecarcinus (Gecarcinus) lateralis quadratus._-Türkay 1970: 338. von Prahl \& Manjarrés 1984: 155.

Gecarcinus quadratus.--Ng et al. 2008: 215. Arzola-González et al. 2010: 187.

Gecarcinus lateralis.-Perger \& Wall 2014: 97.

Gecarcinus quadratus.-Guinot et al. 2018: 568-570. Toledano-Carrasco 2019: 22-26. Ng et al. 2019: 99-100.

Material examined. MEXICO. Sinaloa: 8 males, 2 females, CNCR 362, Municipality Mazatlán, Isla Venados, May 30, 1974, colls. M.C. Chávez, C.A. Martínez.- Nayarit: 2 males, CNCR 33941, Municipality Bahía de Banderas, Punta de Mita, Apr 21, 2017, Coll. Anonymous; 1 male, CNCR 34012, Municipality Bahía de Banderas, Playa Higuera Blanca, Jul 07, 2017, coll. J.L. Villalobos.- Jalisco: 1 female, CNCR 3514, Municipality La Huerta, Playa La Rosada, Bahía de Chamela, Jun 16, 1984, coll. A. Cantú; 1 female, CNCR 3517, Municipality La Huerta, Salinas, Bahía de Chamela, Jun 15, 1984, colls. J.C. Nates, J.L. Villalobos, A. Cantú; 1 male, CNCR 34846, Municipality La Huerta, Estación de Biología Chamela, Instituto de Biología, UNAM, no date, coll. anonymous.- Michoacán: 1 male, CNCR 11736, Municipality Aquila, Playa de Maruata, Jun 20, 1990, coll. M.S. García; 2 females, CNCR 25629, Municipality Lázaro Cárdenas, Río Popoyuta, cerca desembocadura, Jul 12, 1986, coll. A. Raz Guzman; 3 males, 2 females, CNCR 6158, Municipality Aquila, Monte del Oro, km 175 carretera Tecomán-Playa Azul, Mar 03, 1986, coll. R. Lamothe, L.J. Rangel.- Guerrero: 1 male, 1 female, 1 juvenile, CNCR 19003, Municipality La Unión de Isidoro Montes de Oca, Playa Troncones, N of Zihuatanejo, Jan 01, 2001, coll. C. Candelaria.- Oaxaca: 1 male, 1 female, CNCR 34013, Municipality Santa María Tonameca, Playa Aragón, Jan 01, 2017, coll. anonymous; 1 male, 1 female, CNCR 3031, Municipality Santa María Colotepec, Playa El Carrizalillo, Puerto Escondido, Sep 08, 1983, coll. A. Cantú.- Chiapas: 2 males, CNCR 34630, Municipality Tonalá, Barra de Boca del Cielo, Mar 08, 2018, colls. J.L. Villalobos, I. Toledano, E. Moreno.

Diagnosis. Male abdomen triangular; telson triangular, lateral margins straight continuous with those of sixth abdominal somite, slightly marked, tip moderately rounded. Sixth somite with posterior margin as broad as telson or slightly wider, lateral margins forming continued straight margin with telson (Fig. 2F). Female abdomen subcircular, not covering thoracic sternum completely; telson triangular, narrower than posterior margin of sixth somite, lateral margins slightly concave with faint vertical suture at middle (Fig. 3E). Antero-lateral margins of sternites 3-4 widely convex at junction of third maxillipeds, gently concave at level of articulation of first pereiopods (Figs. 2F, 3E). Endostomial ridges (Davie et al. 2015) delimiting efferent branchial channel. Third maxilliped with merus not reaching epistome. 
Description. Carapace transversely oval, wider anteriorly, strongly arched at level of branchial regions, anterolateral margin thin. Regions well-defined, delimited by shallow grooves. Branchial regions prominent. Fronto-orbital margin about half of maximum carapace width (Fig. 1B). Front about 1/4 length of carapace, deflexed, surface slightly concave; inferior margin lightly granulated, not raised from surface, straight, leaving visible basal segments of antennules; frontal lobes poorly defined (Fig. 2E).

Orbits delimited by well defined, smooth, superior border. Infra-orbital margin granulated, interrupted by deep notch, continued as subrectangular or low subtriangular plate forming mesial lobe; area of contact between internal angle of front and mesial lobe of infraorbital margin of variable width (Perger \& Wall 2014), reaching superior border of epistome. Suborbital ridge softly marked, short, extending laterally from superior border of epistome, not reaching subhepatic suture. Third maxillipeds not closing completely, leaving rhomboidal gap; merus not reaching epistome, anterior border straight, occasionally with shallow emargination or discontinuity; ischium with scattered setae on mesial margin, subequal in width to merus, but longer than it (Fig. 2E). Palp short, hidden, articulated behind merus, directed laterally. Exognath hidden behind ischium, without flagellum, not reaching ischium-merus articulation.

Chelipeds in both sexes subequal or similar, evident heterochely in largest males. Chelae with fingers longer than palm, with corneous tips, surface with longitudinal rows of pits and granules, more evident dorsally; cutting margins with distinct subacute tubercles along fingers length, dactyl slightly curved inwards, with 8-10 irregularly spaced small blunt teeth, largest tooth on proximal half; fixed finger with 11-12 irregularly spaced small blunt teeth, largest tooth on distal half; fingers gapping (Fig. 2H). Palm with internal surface smooth, swollen, without tuberculated longitudinal ridge, internal depression next to articulation with carpus. Carpus subtriangular, dorso-mesial margin smooth in large organisms or with spinules in small ones. Merus elongated, subtriangular, inner surface striated, used as stridulatory plectrum.

Pereiopods long, slender with short setae; merus elongated, surface striated, dorsal ridge distally spinulated; carpus subtriangular, shorter than propodus, or almost of same length in fifth pair, distal half of dorsal ridge spinulated; propodus shorter than dactyl, dorsal, ventral and lateral ridges armed with short, thin spines; dactyli armed with 6 rows of spines (Fig. 2G), 5 rows in juveniles.

Male and female abdomen as in species diagnosis.

Male G1, as in genus diagnosis (Fig. 3B, C).

Coloration. Dorsal surface of carapace dark purple, posterior and postero-lateral margins yellow or slightly orange, as well as the ambulatory appendages. Yellow or light orange patches above orbits, and on lower part of front. Chelipeds purple, carpus and merus darker (Fig. 1B).

Measurements. Males: 35.8-54.3 mm CL; 44.9-71.7 mm CW. Females 33- 51.8 mm CL; 38.7-63.9 mm CW.

Remarks. With the resurrection of G. quadratus as a distinct species and geminate analogue from the western Atlantic of G. lateralis, new morphologic and genetic analyses including the eastern Pacific G. nobilii are necessary. According to Perger \& Wall (2014), G. nobilii is distinguished from G. lateralis because the former has a particular coloration: carapace without lighter anterolateral and posterior patches on the light lateral margin, carpus and palm of chelipeds homogeneously red or white. Additionally, the frontal width is distinctly greater than the distance between the mesial ends of the suborbital cristae. Also, the width of the mesial lobe of the infraorbital margin at point of contact with the carapace front is longer than the shortest distance between the carapace front and the mesial end of the suborbital crista (Perger \& Wall 2014).

\section{Discussion}

\section{Phylogenetics and phylogeography}

The two sequenced genes, 16S and COI, showed low variability (haplotype and nucleotide diversity) in G. lateralis and G. quadratus; however, using COI alone it was possible to distinguish two well-supported clades, corresponding to the Atlantic and Pacific specimens. The genetic distance (6.1\%) with COI between G. lateralis and G. quadratus was high in comparison to the within species distance ( $1.1 \%$ and $0.2 \%$, respectively), establishing a clear difference between the two species (Table 3). Similar values in the COI have been obtained in studies with trans-isthmian species, for example, Aratus pisonii H. Milne Edwards, 1853, and A. pacificus Thiercelin \& Schubart, 2014, had 
distances ranging between 4.5 and 5.7\% (Thiercelin \& Schubart 2014). Cryptic new species of the gecarcinid genus Gecarcoidea were erected with smaller distance values, G. humei (Wood-Mason, 1874) had an average distance of $1.47 \%$ and $2.07 \%$ from G. lalandii and G. natalis, respectively (Lai et al. 2017).

Within the Atlantic coast populations of Gecarcinus lateralis, we detected significant departures in terms of genetic distances. The specimens from Boca de Catan, Tamaulipas, Mexico (BCTAM_H2) and those from Puerto Vargas, Costa Rica (PVAR_CR) differ between 2.1 and 2.9\% from the rest, suggesting that more than one species of Gecarcinus might occur along the Atlantic coast.

Divergence time of the Atlantic and Pacific lineages was estimated at 2.3-4.3 million years ago (mya) which coincides with the closure of the Isthmus of Panama that has been dated by several authors in different time ranges: Collins (2003) 4 mya, Coates \& Obando (1996) 2.8-3.1 mya, and Jackson \& O'dea (2013) and Weir et al. (2009) 3-4 mya; however, the exact time of the closure of the Isthmus remains in dispute.

Gecarcinus lateralis from the southwestern Gulf of Mexico and Mexican Caribbean (Arrecife Alacranes, Mahahual and Banco Chinchorro) were genetically very homogeneous and clearly different from the Atlantic populations (La Laguna, La Pesca, Barra de Cazones, Río Prieto, Barra de Sontecomapan, Playa Bruja and Chiltepec). This could indicate the presence of barriers formed by currents inside the Gulf of Mexico, causing a weak connection between the the Bank of Campeche keys (Arcas, Triángulos and Arenas) and the western portion of the gulf, as has been suggested by Johnson et al. (2013), Sanvicente-Añorve et al. (2014), Jordán-Dahlgren (2002) and Oliveira et al. (2018). In the case of $G$. ruricola, it was interesting to note that higher genetic distances separate it from $G$. lateralis and G. quadratus ( $9.6 \%$ and $10.1 \%$, respectively) than from Johngarthia lagostoma (8\%), suggesting that further analyses should be conducted to evaluate the generic divisions.

Within $G$. lateralis some clades were recovered with strong branch supports, relating organisms from the Atlantic of Central America to those from Mexico and not revealing significant differences. In contrast, in G. quadratus only one clade was well-supported, the rest formed a large polytomy that, in addition to the genetic distances, highlight the homogeneous genetic makeup of these populations. Gecarcinus lateralis from Cayo Arcas showed greater genetic affinity with other localities from the Gulf of Mexico rather than with those of Arrecife Alacranes (Fig. 4), which is also considered part of the Campeche Bank Reef System, this is consistent with observations of Sanvicente-Añorve et al. (2014), who suggested that the connection between the keys Arcas, Triángulos and Arenas was higher than with Alacranes (Fig. 8).

The haplotype network obtained for G. lateralis showed a complex structure due to the 16 haplotypes obtained for only 28 individuals (Fig. 7; Table 2). This haplotype diversity can be associated with geological events that have occurred during the Neogene ( 23 mya to present). Two of the vicariant mechanisms that have been considered very important are: 1) the closing of the Isthmus of Panama in the Pliocene, originating sister or geminate species as in the case of Gecarcinus lateralis and G. quadratus, and 2) the periodic glaciations throughout the Neogene, leading to sea level fluctuations and climate changes that fragmented populations that were later connected again. Virtually, all species in the Gulf of Mexico experienced the effects of glaciations, with the most recent event ending 12,000 years ago (Neigel 2009).

TABLE 2. Genetic diversity of mitochondrial COI and $16 \mathrm{~S}$ genes for Gecarcinus lateralis and G. quadratus populations. N: number of sequences used, K: number of polymorphic sites, H: number of haplotypes, Hd: haplotype diversity, $\pi$ : nucleotide diversity.

\begin{tabular}{lllllll}
\hline Gene & Species & $\mathrm{N}$ & $\mathrm{K}$ & $\mathrm{H}$ & $\mathrm{Hd}$ & $\Pi$ \\
\hline COI & G. lateralis & 28 & 28 & 16 & 0.918 & 0.0099 \\
COI & G. quadratus & 11 & 8 & 4 & 0.491 & 0.0023 \\
$16 \mathrm{~S}$ & G. lateralis & 26 & 8 & 5 & 0.498 & 0.0016 \\
$16 \mathrm{~S}$ & G. quadratus & 11 & 15 & 4 & 0.491 & 0.0055 \\
\hline
\end{tabular}

In contrast, in G. quadratus, four haplotypes were found for 11 individuals from Nayarit to Chiapas (Fig. 6; Table 3). This pattern could be the result of either: 1) a higher natural connectivity among populations along the Pacific coast, or 2) population reductions that produced bottlenecks reducing the genetic variability. Arnaud et al. (2000), proposed that some causes of bottlenecks in marine populations can be epidemiological problems, environmental changes or human impact. 
TABLE 3. K2P pairwise nucleotide divergences for COI. Values are given in average percentages.

\begin{tabular}{lllll}
\hline & C. guanhumi & G. quadratus & G. lateralis & G. ruricola \\
\hline G. quadratus & 21.1 & 0.2 & & \\
G. lateralis & 21.6 & 6.1 & 1.1 & \\
G. ruricola & 19.2 & 10.1 & 9.6 & 8 \\
J. lagostoma & 18.6 & 12.8 & 11.8 & 8 \\
\hline
\end{tabular}

\section{Morphology}

The examined crabs from Mexico showed a consistent coloration; however, Perger \& Wall (2014) reported crabs from the Atlantic coast of Costa Rica with a coloration similar to G. quadratus from Mexico, suggesting that coloration was not a good character to separate species. Unfortunately, specimens sheltered in biological collections lose their coloration over the years, hindering the correct identification of old preserved specimens. However, according to Bruce (1975) and Knowlton (1986), live coloration patterns are useful to distinguish among problematic decapod species that differ slightly in their morphology. For instance, in cryptic species of hermit crabs (e.g., Malay \& Paulay 2009), spiny lobsters (Ravago \& Juinio-Meñez 2003), porcelain crabs (Hiller et al. 2006) and the blue crab of Christmas Island Tuerkayana celeste (Ng \& Davie 2012), congruent genetic and coloration differences have been observed.

The shape of sternite 3, as well as the shape of the abdomen and its width, were constant characters in both species and were not size-dependant. These differences were more evident in males (Figs. 2B, F). Overall, the abdomen of G. lateralis females exhibited in most cases an enlarged sixth somite (Figs. 3D, E). This character has been used to distinguish species within the genus Discoplax A. Milne Edwards, 1867, in which there was a slight variation in the shape of the sixth somite in males (Ng \& Shih 2015).

There are strong morphological differences between Johngarthia and Gecarcinus that have already been noted by several authors (e.g., Türkay 1970; Cuesta et al. 2007; Perger et al. 2011). Additionally, Guinot et al. (2018) observed differences in the abdomen locking apparatus; in G. ruricola and G. quadratus (see Köhnk et al. 2017) there is a button, while in Johngarthia there is a large, oblique prominence, both structures covered with setae (Guinot \& Bouchard, 1998, as G. planatus = Johngarthia planata); but in both genera the pleonal sockets are not delineated, so the locking is no longer functional.

In this study we observed significant differences among G. ruricola, G. quadratus and G. lateralis. In the former, the body regions and the frontal lobes are well-defined and divided by a deep median groove, in contrast, these are poorly defined in the two other species (Figs. 2A, E; 3G). Regarding the thoracic sternum, in G. ruricola, sternite 2 is semi-ovate and the lateral margins of sternite 3 are poorly arched, while in the other two species, sternite 2 is trapezoidal and the lateral margins of sternite 3 are convex, being strongly arched in G. quadratus. Also, G. ruricola has a sternite with a well-developed V-shaped suture $2 / 3$ and its congeneric species show a horizontal and faint suture (Figs. 2B, F; 3D-F). In G. ruricola, there is a weak triangular median bridge at level of suture 6/7 and a very narrow one at level of suture 7/8, while in G. quadratus and G. lateralis only some traces of such bridges remain and in Johngarthia the bridges are indistinct (Guinot et al. 2018).

Although in many brachyuran species the morphology of the male gonopod is a key character to distinguish among species (Guinot 1979; Brandis et al. 1999; McLay \& Becker 2015), in the Gecarcinus group there is very little morphological variation, not enough to distinguish among species.

All the genetic analyses and morphological observations made by Guinot et al. (2018) suggest that a new genus, which includes G. lateralis, G. quadratus and G. nobilii, should be erected, since G. ruricola shows significant differences when compared to its congeneric species and to Johngarthia.

\section{Acknowledgements}

The first author gratefully acknowledges CONACYT for scholarship number 455843 and the Programa de Posgrado en Ciencias Biológicas (PCB) - UNAM for their support. We also thank Christoph Schubart (Universität Regensburg, Germany) and Fernando Mantelatto (UNESP, Brazil), for donating tissue of two pereiopods of G. ruricola and two sequences of G. lateralis from Costa Rica and one from Panama, respectively. We thank Gabino Rodríguez (CCLEA-Universidad Autónoma de Nuevo León) and Nuno Simoes (CCY — Unidad Multidisciplinaria de Docen- 
cia e Investigación, Facultad de Ciencias, Universidad Nacional Autónoma de México), for all the facilities to consult the gecarcinid specimens of their crustacean collections. Susana Guzmán Gómez, Laura Márquez Valdemar and Andrea Jiménez Marín, from the Thematic Laboratories at IB/UNAM, for their technical advice on the photographs of the gonopods (SGG) and their support to conduct DNA sequencing (LMV, AJM). Finally, we do acknowledge the advice of Rafael Robles, Juan Carlos Ojeda and Eric Moreno on the molecular analyses and field work.

\section{References}

Abele, L.G., Robinson, M.H. \& Robinson, B. (1973) Observations on sound production by two species of crabs from Panama (Decapoda, Gecarcinidae and Pseudothelphusidae). Crustaceana, 25 (2), 147-152. https://doi.org/10.1163/156854073X00795

Abele, L.G. \& Kim, W. (1986) An illustrated guide to the marine decapod crustaceans of Florida. Department of Environmental Regulation, State of Florida. Technical Series, 8 (1), 1-760. [https://decapoda.nhm.org/pdfs/12365/12365-001.pdf]

Arnaud, S., Monteforte, M., Galtier, N., Bonhomme, F. \& Blanc, F. (2000) Population structure and genetic variability of pearl oyster Pinctada mazatlanica along Pacific coasts from Mexico to Panama. Conservation Genetics, 1, $299-308$. https://doi.org/10.1023/A:1011575722481

Arzola-González, J.F., Flores-campaña, L.M. \& Vázquez-C, A. (2010) Crustáceos decápodos intermareales de las islas de la costa de Sinaloa, México. Universidad y Ciencia, 26 (2), 179-193. [http://www.scielo.org.mx/pdf/uc/v26n2/v26n2a6.pdf]

Bandelt, H.J., Forster, P. \& Rohl, A. (1999) Median-joining networks for inferring intraspecific phylogenies. Molecular Biology and Evolution, 16 (1), 37-48.

https://doi.org/10.1093/oxfordjournals.molbev.a026036

Bliss, D. (1963) The pericardial sacs of terrestrial Brachyura. In: Whittington, H.B. \& Rolfe, W.D.I. (Eds.), Phylogeny and Evolution of Crustacea. Museum of Comparative Zoology, Special Publication, Harvard University, Cambridge, Massachusetts, pp. 59-78.

Bliss, D. (1968) Transition from water to land in decapod crustaceans. American Zoologist, 8 (3), 355-392. https://doi.org/10.1093/icb/8.3.355

Brandis, D., Storch, V. \& Türkay, M. (1999). Morphology and function of the copulatory system in freshwater crabs of the genus Potamon. Journal of Morphology, 239, 157-166. https://doi.org/10.1002/(SICI)1097-4687(199902)239:2<157::AID-JMOR4>3.0.CO;2-E

Bruce, A.J. (1975) Coral reef shrimps and their color patterns. Endeavour, 34, 23-27. https://doi.org/10.1016/0160-9327(75)90064-2

Chace, F.A. Jr. \& Hobbs, H.H. Jr. (1969) The freshwater and terrestrial decapod crustaceans of de West Indies with special reference to Dominica. Bulletin of United States National Museum, 292, 1-256. https://doi.org/10.5479/si.03629236.292.1

Coates, A.G. \& Obando, J.A. (1996) The geologic evolution of the Central American Isthmus. In: Jackson, J.B.C., Budd, A.F. \& Coates, A.G. (Eds.), Evolution and Environment in Tropical America. The University of Chicago Press, Chicago, Illinois, pp. $21-56$.

Collins, L.S. (2003) Micropaleontological evidence for closure of the Central American Seaway. Geological Society of America, Abstracts with Programs, 34 (7), 85.

Cuesta, J.A., García-Guerrero, M. \& Hendrickx, M.E. (2007) The complete larval development of Johngarthia planatus (Brachyura: Grapsoidea: Gecarcinidae) described from laboratory reared material, with notes on the affinity of Gecarcinus and Johngarthia. Journal of Crustacean Biology, 27 (2), 263-277. https://doi.org/10.1651/C-2642.1

Daniels, S.R., Gouws, G. \& Crandall, K.A. (2006) Phylogeographic patterning in a freshwater crab species (Decapoda: Potamonautidae: Potamonautes) reveals the signature of historical climatic oscillations. Journal of Biogeography, 33, 15381549. https://doi.org/10.1111/j.1365-2699.2006.01537.x

Darriba, D., Taboada, G.L., Doallo, R. \& Posada, D. (2012) jModelTest 2: more models, new heuristics and parallel computing. Nature Methods, 9 (8), 772. https://doi.org/10.1038/nmeth.2109

Davie, P.J.F., Guinot, D. \& Ng, P.K.L. (2015) Anatomy and functional morphology of Brachyura (Chapter 71-2). In: Castro, P., Davie, P.J.F., Guinot, D., Schram, F.R. \& von Vaupel Klein, J.C. (Eds.), Decapoda: Brachyura, Treatise on Zoology - Anatomy, Taxonomy, Biology. Vol. 9C-1. Crustacea, Brill, Leiden and Boston, pp. 11-163. [https://www.researchgate. net/publication/296696404_Davie_PJF_Guinot_D_Ng_PKL_2015a_Anatomy_and_functional_morphology_of_Brachyura_In_Castro_P_Davie_PJF_Guinot_D_Schram_- F_Von_Vaupel_Klein_C_Eds_Treatise_on_Zoology_-_Anatomy_Taxonomy_Biology_-_The_Crust]

De Oliveira, T.S. (2014) Modificações esqueletais e apendiculares torácicas para captação de água do solo em caranguejos semiterrestres (Crustacea: Brachyura: Grapsoidea: Ocypodoidea). Dissertacao Mestrado en Sistemática, Taxonomia Animal e Biodiversidade. Museu de Zoologia, Université de São Paulo. Available from: http://www.teses.usp.br/teses/dis- 
poniveis/38/38131/tde-26112014-202417/ (accessed 21 September 2021)

De Saussure, H. (1853) Description de quelques crustaces nouveaux de la cote occidentale du Mexique. Revue et Magasin de Zoologie, 5 (2), 354-368. [https://www.biodiversitylibrary.org/item/48709\#page/384/mode/1up]

De Saussure, H. (1858) Mémoire sur divers Crustacés nouveaux des Antilles et du Mexique. Memoires de la Société de physique et d'histoire naturelle de Genève, 14, 417-496. [https://www.biodiversitylibrary.org/item/41153\#page/585/mode/1up]

Felder, D.L., Álvarez, F., Goy, J.W. \& Lemaitre, R. (2009) Decapoda (Crustacea) of the Gulf of Mexico, with Comments on the Amphionidacea. In: Felder, D.L. \& Camp, D.K. (Eds.), Gulf of Mexico origin, waters, and biota. Texas A\&M University Press, U.S.A., pp. 1019-1104. [https://research.nhm.org/pdfs/31408/31408.pdf]

Folmer, O., Black, M., Hoech, W., Lutz, R. \& Vrijenhoek, R. (1994) DNA primers for amplification of mitochondrial cytochrome c oxidase subunit I from diverse metazoan invertebrates. Molecular Marine Biology and Biotecnology, 3, $294-299$. [https://www.mbari.org/wp-content/uploads/2016/01/Folmer_94MMBB.pdf]

Fréminville, M. (1835) Notice sur les tourlouraux ou crabes de terre des Antilles. Annales des Sciences Naturelles, Zoologie, 2 (2), 213-224. [https://www.biodiversitylibrary.org/item/111230\#page/219/mode/1up]

Garth, J.S. (1948) The Brachyura of the Askoy Expedition, with remarks on Carcinological Collections in the Panama Bight. Bulletin of the American Museum of Natural History, 92, 1-66. https://decapoda.nhm.org/pdfs/27475/27475.pdf

Greenaway, P. (1988) Ion and water balance. In: Burggren, W.W. \& Mcmahon, B.R. (Eds.), Biology of the Land Crabs. Cambridge University Press, Cambridge, pp. 211-248. https://doi.org/10.1017/CBO9780511753428.008

Griffiths, M.E., Mohammad, B.A. \& Vega, A. (2007) Dry season distribution of land crabs, Gecarcinus quadratus (Crustacea: Gecarcinidae), in Corcovado National Park, Costa Rica. Revista de Biología Tropical, 55, 219-224. https://doi.org/10.15517/rbt.v55i1.6073

Guérin, F.E. (1829-1837) Crustacés. In: Baillière, J.B., Iconographie du Règne animal de G. Cuvier, ou représentation d'après nature de l'une des espèces les plus remarquables et souvent encore non figurées, de chaque genre d'animaux. Avec un texte descriptif mis au courant de la science. Ouvrage pouvant servir d'atlas a tous les traités de zoologie. Paris and London, 3 [1-4], 426 pp. [https://www.biodiversitylibrary.org/item/28193\#page/63/mode/1up]

Guinot D. (1979) Données nouvelles sur la morphologie, la phylogenèse et la taxonomie des Crustacés Décapodes Brachyoures. Mémoires du Muséum national d'Histoire naturelle, Nouvelle Série, Série A, Zoologie, 112, 3-354. [https://decapoda.nhm. org/pdfs/11004/11004.pdf]

Guinot, D. \& Bouchard, J.-M. (1998) Evolution of the abdominal holding systems of brachyuran crabs (Crustacea, Decapoda, Brachyura). Zoosystema, 20 (4), 613-694. [https://www.researchgate.net/publication/285941226_Evolution_of_the_abdominal_holding_systems_of_brachyuran_crabs_Crustacea_Decapoda_Brachyura]

Guinot, D., $\bar{N}$, N.K. \& Moreno, P.A.R. (2018) Review of grapsoid families for the establishment of a new family for Leptograpsodes Montgomery, 1931, and a new genus of Gecarcinidae H. Milne-Edwards, 1837 (Crustacea, Decapoda, Brachyura, Grapsoidea MacLeay, 1838). Zoosystema, 40, 547-605. https://doi.org/10.5252/zoosystema2018v40a26

Hendrickx, M.E. (1995) Checklist of brachyuran crabs (Crustacea: Decapoda) from the Eastern Tropical Pacific. Bulletin de l'Institut royal des Sciences naturelles de Belgique, 65, 125-150. [https://www.researchgate.net/publication/286334670_ Checklist_of_brachyuran_crabs_Crustacea_Decapoda_from_the_eastern_tropical_Pacific]

Hermoso-Salazar, M. \& Arvizu-Coyotzi, K. (2015) Crustáceos del Sistema Arrecifal Veracruzano. In: Granados-Barba, A., Ortiz-Lozano, L.D., Salas-Monreal, D. \& Gonzalez-Gándara, C. (Eds.), Aportes al conocimiento del Sistema Arrecifal Veracruzano: hacia el corredor arrecifal del noroeste del Golfo de México. Universidad Veracruzana, México, pp. 1-26. [https://www.researchgate.net/publication/284673032_Crustaceos_del_Sistema_Arrecifal_Veracruzano]

Hernández-Aguilera, J.L., Toral-Almazan, R.E. \& Ruiz-Nuño, J.A. (1996) Éspecies catalogadas de Crustáceos estomatópodos y decápodos para el Golfo de México, Río Bravo, Tamps. A Progreso, Yuc. DGONSM-CONABIO, México, D.F., 132 pp. [http://www.conabio.gob.mx/institucion/proyectos/resultados/FichapubB035.pdf]

Hiller, A., Kraus, H., Almon, M. \& Werding, B. (2006) The Petrolisthes galathinus complex: species boundaries based on color pattern, morphology and molecules, and evolutionary interrelationships between this complex and other Porcellanidae (Crustacea: Decapoda: Anomura). Molecular Phylogenetics and Evolution, 40, 547-569.

https://doi.org/10.1016/j.ympev.2006.03.030

Jackson, J.B. \& O'dea, A. (2013) Timing of the oceanographic and biological isolation of the Caribbean Sea from the tropical eastern Pacific Ocean. Bulletin of Marine Science, 4, 779-800. https://doi.org/10.5343/bms.2012.1096

Johnson, D.R., Perry, H.M. \& Lyczkowski-Shultz, J. (2013) Connections between Campeche Bank and red snapper populations in the Gulf of Mexico via modeled larval transport. Transactions of the American Fisheries Society, 142, 50-58. https://doi.org/10.1080/00028487.2012.720630

Jones, C.G., Lawton, J.H. \& Snachak, M. (1994) Organisms as ecosystem engineers. Oikos, 69, 373-386. https://doi.org/10.2307/3545850

Jordán-Dahlgren, E. (2002) Gorgonian distribution patterns in coral reefs environments of the Gulf of Mexico: evidence of sporadic ecological connectivity?. Coral Reefs, 21, 205-215.

https://doi.org/10.1007/s00338-002-0226-9 
Kang, J.H., Noh, E.S., Park, J.Y., An, C.M., Choi, J.H. \& Kim, J.K. (2015) Rapid origin determination of the Northern Mauxia Shrimp (Acetes chinensis) based on allele specific polymerase chain reaction of partial mitochondrial 16S rRNA gene. Asian-Australasian Journal of Animal Sciences, 28, 568-572. https://doi.org/10.5713/ajas.14.0613

Katoh, K. \& Standley, D.M. (2013) MAFFT multiple sequence alignment software version 7: improvements in performance and usability. Molecular Biology and Evolution, 30 (4), 772-780. https://doi.org/10.1093/molbev/mst010

Kimura, M. (1980) A simple method for estimating evolutionary rates of base substitutions through comparative studies of nucleotide sequences. Journal of Molecular Evolution, 16, 111-120. https://doi.org/10.1007/BF01731581

Klaassen, F. (1973) Stridulation und Komminikation durch Substratschall bei Gecarcinus lateralis (Crustacea Decapoda). Journal of Comparative Physiology, 83, 73-79. https://doi.org/10.1007/BF00694574

Knowlton, N. (1986) Cryptic and sibling species among the decapod Crustacea. Journal of Crustacean Biology, 6, 356-363. https://doi.org/10.2307/1548175

Knowlton, N., Weigt, L.A., Solórzano, L.A., Mills, D.K. \& Bermingham, E. (1993) Divergence in proteins, mitochondrial DNA, and reproductive compatibility across the Isthmus of Panama. Science, 260 (5114), 1629-1632. https://doi. org/10.1126/science. 8503007

Knowlton, N. \& Weigt, L.A. (1998) New dates and new rates for divergence across the Isthmus of Panama. Proceedings of the Royal Society of London. Biological sciences Royal Society. Series B, 265, 2257-2263. https://doi.org/10.1098/rspb.1998.0568

Köhnk, S., Gorb, S. \& Brandis, D. (2017) The morphological and functional variability of pleon-holding mechanisms in selected Eubrachyura (Crustacea: Decapoda). Journal of Natural History, 51 (35-36), 2087-2132. https://doi.org/10.1080/00222933.2017.1355076

Kumar, S., Stecher, G. \& Tamura, K. (2016) MEGA7: Molecular Evolutionary Genetics Analysis Version 7.0 for Bigger Datasets. Molecular Biology and Evolution, 33 (7), 1870-1874. https://doi.org/10.1093/molbev/msw054

Lai, J.C.Y., Shih, H.-T. \& Ng, P.K.L. (2017) The systematics of land crabs of the genus Gecarcoidea and recognition of a pseudocryptic species, G. humei, from the eastern Indian Ocean (Crustacea: Decapoda: Gecarcinidae). Invertebrate Systematics, 31, 406-426. https://doi.org/10.1071/IS16052

Latreille, P.A. (1828) Tourlouroux. Encyclopedic Methodique: Histoire naturelle, entomologie, ou historic naturelle des Crustaces, des Arachnides, et des Insectes, 10, 681-685. [https:/www.biodiversitylibrary.org/item/32580\#page/691/mode/1up]

Leach, W.E. (1814) Crustaceology. In: Brewster, D. (Ed.), The Edinburgh Encyclopaedia. 7 (2). Balfour, Edinburgh, PP. 383437. [https://www.biodiversitylibrary.org/item/114403\#page/479/mode/1up]

Linnaeus, C. (1758) Systema Naturae per Regna Tria Naturae, Secumdum Classes, Ordines, Genera, Species, cum Characteribus, Differentiis Specierum, Synonymis, Locis. Vol. 1. Impensis Direct. Laurentii Salvii, Holmiae, 824 pp. [https://www. biodiversitylibrary.org/item/10277\#page/647/mode/1up]

Low, M.E.Y., Ng, P.K.L. \& Evenhuis, N.L. (2013) Names and publication dates of the Brachyura in F.É. Guérin (Guérin-Méneville) (Crustacea: Decapoda). Zootaxa, 3736 (2), 101-127. https://doi.org/10.11646/zootaxa.3736.2.1

Malay, M.C.D. \& Paulay, G. (2009) Peripatric speciation drives diversification and distribution patterns of reef hermit crabs (Decapoda: Diogenidae: Calcinus). Evolution, 64, 634-662. https://doi.org/10.1111/j.1558-5646.2009.00848.x

McGaw, I.J., Van Leeuwen, T.E., Trehern, R.H. \& Bates, A.E. (2019). Changes in precipitation may alter food preference in an ecosystem engineer, the black land crab, Gecarcinus ruricola. PeerJ, 7, e6818. https://doi.org/10.7717/peerj.6818

McLay, C.L. \& Becker, C. (2015) Reproduction in Brachyura (Chapter 71-4). In: Castro, P., Davie, P.J.F., Guinot, D., Schram, F.R. \& von Vaupel Klein, J.C. (Eds.), Decapoda: Brachyura, Treatise on Zoology-Anatomy, Taxonomy, Biology. Vol. 9C1. Crustacea, Brill, Leiden and Boston, pp. 185-243. https://doi.org/10.1163/9789004190832_004

Miller, M.A., Pfeiffer, W. \& Schwartz, T. (2010) "Creating the CIPRES Science Gateway for inference of large phylogenetic trees”. Gateway Computing Environments Workshop (GCE), New Orleans, Louisiana, pp. 1-8. https://doi.org/10.1109/GCE.2010.5676129

Milne-Edwards, A. (1867) Description de quelques especes nouvelles de Crustaces Brachyoures. Annales de la Societe Entomologique de France, 7 (4), 263-288. [https://www.biodiversitylibrary.org/item/101298\#page/287/mode/1up]

Milne-Edwards, H. (1837) Histoire naturelle des Crustacés, comprenant lánatomie, la physiologie et la classification de ces animaux. Vol. 2. Atlas $(1834,1837,1840)$. Librairie encyclopédique de Roret, Paris, 532 pp. https://doi.org/10.5962/bhl.title.6234

Neigel, J.E. (2009) Population Genetics and Biogeography of the Gulf of Mexico (1353-1363 p.). In: Felder, D.L. \& Camp, D.K. (Eds.), Gulf of Mexico origin, waters, and biota. Texas A\&M University Press, College Station, Texas, pp. 1-1374. 
[https://scholar.google.com.mx/scholar?q=Neigel,+J.E.+(2009)+Population+Genetics + and + Biogeography + of + the + Gulf + of + Mexico\&hl=es\&as_sdt $=0 \&$ as_vis $=1 \&$ oi $=$ scholar]

Ng, N.K., Rodríguez Moreno, P.A., Naruse, T., Guinot, D. \& Mollaret, N. (2019) Annotated type-catalogue of Brachyura (Crustacea, Decapoda) of the Muséum national d'Histoire naturelle, Paris. Part II. Gecarcinidae and Grapsidae (Thoracotremata, Grapsoidea), with an Appendix of pre-1900 collectors. Zoosystema, 41 (7), 91-130.

https://doi.org/10.5252/zoosystema2019v41a7

Ng, P.K.L., Guinot, D. \& Davie, P.J.F. (2008) Systema Brachyurorum: Parte I. An annotated checklist of extant brachyuran crabs of the world. The Raffles Bulletin of Zoology (Supplement), 17, 1-286. [http://citeseerx.ist.psu.edu/viewdoc/download?doi $=10.1 .1 .649 .2033 \& \mathrm{rep}=\mathrm{rep} 1 \&$ type $=\mathrm{pdf}]$

Ng, P.K.L. \& Davie, P.J.F. (2012) The Blue Crab of Christmas Island, Discoplax celeste, new species (Crustacea: Decapoda: Brachyura: Gecarcinidae). The Raffles Bulletin of Zoology, 60 (1), 89-100. [https://lkcnhm.nus.edu.sg/wp-content/uploads/ sites/10/app/uploads/2017/06/60rbz089-100.pdf]

Ng, P.K.L. \& Shih, H.T. (2015) The land crabs of the Discoplax longipes A. Milne-Edwards, 1867 species group, with description of a new species from Guam (Crustacea: Decapoda: Brachyura: Gecarcinidae). Zootaxa, 3980 (3), $379-405$. https://doi.org/10.11646/zootaxa.3980.3.3

Oliveira, C.M.C.A., Terossi, M. \& Mantelatto F.L. (2018) Phylogeographic structuring of the amphidromous shrimp Atya sacabra (Crustacea, Decapoda, Atyidae) unveiled by range-wide mitochondrial DNA sampling. Marine and Freshwater Research, 70 (8): 1078-1093.

https://doi.org/10.1071/MF18272

Perger, R. \& Wall, A. (2014) The description of a new species of the Neotropical land crab genus Gecarcinus Leach, 1814 (Crustacea, Decapoda, Brachyura, Gecarcinidae). ZooKeys, 435, 93-109.

https://doi.org/10.3897/zookeys.435.7271

Perger, R., Vargas, R. \& Wall, A. (2011) Johngarthia cocoensis, a new species of Gecarcinidae MacLeay, 1838 (Crustacea, Decapoda, Brachyura) from Cocos Island, Costa Rica. Zootaxa, 2911 (1), 57-68. https://doi.org/10.11646/zootaxa.2911.1.4

Pocock, R.I. (1889) On the Arachnida, Myriopoda and land-Crustacea of Christmas Island. Proceedings of the Zoological Society of London, 1888, 556-564. https://doi.org/10.1111/j.1469-7998.1888.tb06733.x

Powers, L.W. (1977) A catalogue and bibliography to the crabs (Brachyura) of the Gulf of Mexico. Contributions in Marine Science, Supplement, 20, 3-190. [https://research.nhm.org/pdfs/4119/4119.pdf]

Rambaut, A. (2014) FigTree. Vesion 1.4.2. Available from: http://tree.bio.ed.ac.uk/software/figtree/ (accessed 21 September 2021)

Rambaut, A., Suchard, M.A., Xie, D. \& Drummond, A.J. (2014) Tracer. Version 1.6. Available from: http://beast.bio.ed.ac. uk/Tracer (accessed 21 September 2021)

Rathbun, M.J. (1918) The grapsoid crabs of America. Bulletin of the United States National Museum, 97, 1-461. https://doi.org/10.5479/si.03629236.97.i

Ravago, R.G. \& Juinio-Meñez, M.A. (2003) Phylogenetic position of the stripedlegged forms of Panulirus longipes (A. MilneEdwards, 1868) (Decapoda, Palinuridae) inferred from mitochondrial DNA sequences. Crustaceana, 75, 1047-1059. https://doi.org/10.1163/156854002763270455

Ronquist, F., Teslenko, M., Mark, P. Van der, Ayres, D.L., Darling, A., Höhna, S., Larget, B., Liu, L., Suchard, M.A. \& Huelsenbeck, J.P. (2012) 'MrBayes 3.2: Efficient Bayesian Phylogenetic Inference and Model Choice Across a Large Model Space'. Systematic Biology, 61, 539-42.

https://doi.org/10.1093/sysbio/sys029

Sanvicente-Añorve, L., Zavala-Hidalgo, J., Allende-Arandía, M.E. \& Hermoso-Salazar, M. (2014) Connectivity patterns among coral reef systems in the southern Gulf of Mexico. Marine Ecology Progress Series, 498, $27-41$. https://doi.org/10.3354/meps10631

Schubart, C.D., Cannicci, S., Vannini, M. \& Fratini, S. (2006) Molecular phylogeny of grapsoid crabs (Decapoda, Brachyura) and allies based on two mitochondrial genes and a proposal for refraining from current superfamily classification. Journal compilation, JZS 44 (3), 193-199.

https://doi.org/10.1111/j.1439-0469.2006.00354.x

Sherman, P.M. (2003) Influence of land crabs Gecarcinus quadratus (Gecarcinidae) on distributions of organic carbon and roots in a Costa Rican rain forest. Revista de Biología Tropical, 54, 149-161. https://doi.org/10.15517/rbt.v54i1.13987

Stimpson, W. (1860) Notes on North American Crustacea, in the museum of the Smithsonian Institution, No II. Annals of Lyceum of Natural History of New York, 7, 176-246, pls. T. 2, 5. https://doi.org/10.1111/j.1749-6632.1862.tb00153.x

Suchard, M.A., Lemey, P., Baele, G., Ayres, D.L., Drummond, A.J. \& Rambaut, A. (2018) Bayesian phylogenetic and phylodynamic data integration using BEAST 1.10. Virus Evolution, 4 (1), vey016. https://doi.org/10.1093/ve/vey016

Thiercelin, N. \& Schubart, C.D. (2014) Transisthmian differentiation in the tree-climbing mangrove crab Aratus H. Milne Edwards, 1853 (Crustacea, Brachyura, Sesarmidae), with description of a new species from tropical eastern Pacific. Zootaxa, 
$3793(5), 545-560$.

https://doi.org/10.11646/zootaxa.3793.5.3

Toledano-Carrasco, I.A. (2019) Revisión filogenética de las especies de cangrejos semiterrestres pertenecientes al género Gecarcinus Leach, 1814 (Brachyura: Grapsoidea: Gecarcinidae) de México. Tesis de Maestría, Universidad Nacional Autónoma de México, México, 95 pp. [http://132.248.9.195/ptd2018/diciembre/0783828/Index.html]

Türkay, M. (1970) Die Gecarcinidae Amerikas. Miteinem Anhangüber Ucides Rahbun (Crustacea: Decapoda). Senckenbergiana Biologica, 51 (5/6), 333-354. [https://research.nhm.org/pdfs/27369/27369.pdf]

Türkay, M. (1973) Bemerkungen zu einigen Landkrabben (Crustacea, Decapoda). Bulletin du Muséum National D’Histoire Naturelle, (142), 969-978. [https://decapoda.nhm.org/pdfs/31464/31464.pdf]

von Prahl, H. \& Manjarrés, G. (1984) Cangrejos Gecarcínidos (Crustacea; Gecarcinidae) de Colombia. Caldasia, 14 (66), 149-168. [https://revistas.unal.edu.co/index.php/cal/article/view/34905/35174]

Weir, J.T., Bermingham, E. \& Schluter, D. (2009) The Great American Biotic Interchange in birds. Proceedings of the National Academy of Sciences, 106, 21737-21742. https://doi.org/10.1073/pnas.0903811106

Wolcott, T.G. (1984) Uptake of soil interstitial water: mechanisms and ecological significance in the ghost crab Ocypode quadrata and two gecarcinid land crabs. Physiological Zoology, 57 (1), 161-184. https://doi.org/10.1086/physzool.57.1.30155978

Wood-Mason, J. (1874) On a new genus and species (Hylaeocarcinus humei) of landcrabs from the Nicobar Islands. Annals \& Magazine of Natural History, 14, 187-191. https://doi.org/10.1080/00222937408680954

Young, C.G. (1900) The stalk-eyed Crustacea of British Guiana, West Indies and Bermuda. Nature, 64, 98-99. https://doi.org/10.1038/064098a0 